Article

\title{
Design of an Open Platform for Multi-Disciplinary Approach in Project-Based Learning of an EPICS Class
}

\author{
Ha Quang Thinh Ngo ${ }^{1}\left[\right.$ and Mai-Ha Phan ${ }^{2, *}$ \\ 1 Department of Mechatronics Engineering, HCMC University of Technology, Vietnam National \\ University-Ho Chi Minh City (VNU-HCM), Ho Chi Minh City 700000, Vietnam; nhqthinh@hcmut.edu.vn \\ 2 Department of Industrial Systems Engineering, HCMC University of Technology, Vietnam National \\ University-Ho Chi Minh City (VNU-HCM), Ho Chi Minh City 700000, Vietnam \\ * Correspondence: ptmaiha@hcmut.edu.vn
}

Received: 31 December 2018; Accepted: 3 February 2019; Published: 10 February 2019

\begin{abstract}
Nowadays, global engineers need to be equipped with professional skills and knowledge to solve 21st century problems. The educational program, created in digital learning rooms of the Higher Engineering Education Alliance Program (HEEAP) program supported by Arizona State University, became a pioneer in teaching learners to work within the community. First, the combination of a novel instructional strategy and an integrated education in which project-based approach is employed to apply the technical knowledge. During this, students in mechatronics, computer science, and mechanics must collaborate with peers from industrial systems engineering. Second, in this paper, the design of an open structure connecting multi-disciplinary major is illustrated with a new teaching approach. It is proved to be better by combining specialized understandings of various types in a wide range of applications. From this basis support, participants could implement additional components quickly while keeping the cost low, making the products feasible and user-friendly. Last but not least, students are facilitated with a free library that helps to control simply despite lacking experience in robotics or automation. Several examples show that students are capable of developing things by themselves on open design. In brief, this platform might be an excellent tool to teach and visualize the practical scenario in a multi-disciplinary field.
\end{abstract}

Keywords: service learning; robotics; open platform; automated vehicle; EPICS

\section{Introduction}

Currently, universities are improving their undergraduate programs to apply the teaching trend based on science, technology, engineering, and math (STEM). Their purpose is to develop both students' skills and attitudes simultaneously with knowledge obtained before. The integrated subjects of these skills are often focused. A project-based learning method is used to teach students skills and attitudes towards team work and self-studying. For many programs, the coursework project is basically a specialized background to apply a project-based learning method (PBL). However, in order to develop multi-disciplinary skills, projects should be organized to allow students from different majors to work in groups to solve certain practical problems. With that idea, the Engineering Projects In Community Service (EPICS) course is a good way to effectively implement skills training for students. Founded at Purdue University in Fall 1995, EPICS courses are taught in 35 universities so far [1]. EPICS is a service-learning design course where teams of students collaborate on long-term projects that contribute to the community [2]. Project work concentrates on engineering and technology needs of a community partner while interdisciplinary team interaction is an essential element for project success. 
EPICS is a model that has been recognized within engineering education globally. Teaching EPICS according to PBL method helps the teams design, build, and deploy systems to solve engineering-based problems. The EPICS course is organized for students from different backgrounds to work on multi-disciplinary practical problems from life or industries. Occasionally, lecturers, as an instructor role in the working process, do not have sufficient in-depth knowledge in all areas, which is a big challenge for EPICS classes. This paper suggests a feasible solution: to create open learning resources for in-depth knowledge and deploy a flipped classroom to introduce basic knowledge to relevant STEM issues for EPICS course. The application of open learning resources for an EPICS course is implemented for the Faculty of Mechanical Engineering, comprised of Mechanical Engineering, Mechatronics Engineering, Industrial Systems Engineering, Logistics and Supply Chain Management, and so on.

The more projects that are associated with the development trend, the more they support students to quickly meet employers' requirements. With the goal of deploying EPICS course into undergraduate programs at the Faculty of Mechanical Engineering, combined with the development trend of society, projects that match are analyzed. One easily recognized trend in the industry 4.0 is the need for automation in global logistics operations.

In that trend, logistics is concerned with the arrangements and movement of material and people. While procurement, inventory, transportation, warehouse, and distribution management are all important components, logistics is concerned with the integration of these and they are related to create time and space value for organizations. Logistics providers are required to do more transactions, in smaller quantities, in a shorter time, at minimum cost, and with greater accuracy. New trends, such as mass customization and e-commerce, are intensifying these demands. To maximize the value in a logistics system, various planning decisions need to be made, from task-level choice of which items to pick next for order fulfillment to strategic level decisions of investing an automatic handling machine system or not.

Furthermore, e-commerce development leads to increasing demand for transporting goods. Businesses that invest in automatic handling systems will have the advantage due to the precise positioning of the desired goods despite the small quantity. One of the pieces of handling equipment that is commonly used in warehouses that meets automation needs is an automatic guided vehicle (AGV). Therefore, designing AGV to cope with the logistics system needs is a promising topic at the moment. After analyzing this trend in the industry, the university proposed the EPICS course for students in mechanical engineering, mechatronics, computer science, and industrial engineering to work in groups with the direction on an AGV design.

\section{Literature Review}

\subsection{Project-Based Learning in a Specilized Subject}

For applying a PBL approach to a specialized subject, there are previous studies reporting the teaching experience and authors' reflection. Nasser et al. [3] spent their time in a power electrical system engineering subject via technical projects for students. They recognized that PBL helps with providing both professional attitude and skills. However, they lacked criteria to choose suitable projects in the first stage. This resulted in there being impractical or obsolete knowledge discussed. In a similar approach with a different manner, Aaron et al. [4] presented a process to develop, implement, and assess a project-based bioinstrumentation course. The learners must apply principles or theories of the course to design their devices. Authors innovated two assessments: direct assessment, which is evaluated via exercises related to constructing the benchmarks, and an indirect one through surveys. The direct rating is done at the end of the course to avoid bias in grading while the indirect rating is collected before and after the course. The indirect and direct evaluation with respect to learning outcome provides evidence to determine whether there was significant improvement in student-perceived skills. There were no prerequisite subjects or skills for enrolling in the course. A one-term period is insufficient to build up a 
bioinstrumentation device, so teachers in [5] focused on a semi-autonomous vehicle project divided into several stages. Design of a project requires detailed planning, an extensive literature survey, and comprehensive hardware and software design. They delivered basic control system knowledge to students such as circuit design, practical control theory, and hardware implementation. In each stage, understanding in analog and digital electronics, sensors and actuators, control, and power were detailed. In addition, extensive experiments were conducted to emphasize the lateral distance, speed control performance, and obstacle avoidance ability. Via this project, students learnt how to solve control problems, planning, survey, reading technical datasheets, and validation. Although mentors can be an expert in the control field, the process of studying was not open to feedback from participants, along with there being the absence of learning outcomes.

Regarding the other concern of PBL, the cooperative learning in a project becomes one of the key topics. In [6,7], Laio et al. introduced an agent-based simulation that focuses on students allows testing of various situations for project-based learning applications. In this test, the assessment methodology for student's perception in PBL activities is verified on a partial least squares path modeling. The theory assumed that the learning rate of a team of agents with different educational levels and amount of instruction given is different in a proposed simulation environment. However, the results of simulation were only validated in soft skills, not in technical courses.

\subsection{PBL in a Flipped Classroom}

PBL is a comprehensive approach to classroom activities that is designed to engage students in working on authentic problems [8]. Barron et al. in [9] remains valid until today. They shared a perspective to design, implement, and evaluate problems including project-based curricula that emerged from a long-term collaboration with teachers. Their four design principles are: (1) defining learning-appropriate goals towards deep understanding; (2) providing scaffolds such as "embedded teaching," "teaching tools," set of "contrasting cases," and an overview of problem-based learning activities before initiating projects; (3) ensuring multiple opportunities for informative self-assessment and revision; and (4) developing social structures that promote participation and a sense of agency. Similarly, this paper also designed the goal for the coursework project, which is the application of EPICS and an automation handling system that serves in logistics by applying the PBL method (principle 1). The support tool for deployment is a model that proposed an open platform along with a flipped classroom model (principle 2). Some issues related to principles 3 and 4 are also discussed in the previous section.

Thomas J.W. [10] reviews all studies on PBL in the past ten years and divided them into eight topics: definition, underpinning, effectiveness, role of student characteristics, implementation, intervention, conclusions and future. There is evidence that: (1) students and teachers believe PBL is beneficial and effective as an instructional method; (2) PBL, in comparison to other instructional methods, has value for enhancing the quality of students' learning in the concerned areas; (3) PBL is an effective method for teaching students complex processes and procedures such as planning, communicating, problem solving, and decision making; (4) PBL is relatively challenging to plan and enact; and (5) students have difficulties benefiting from self-directed situations, especially in complex projects.

Stephanie B. [11] also acknowledges the innovative approach of PBL for success in the twenty-first century. Student should drive their own learning through inquiry, as well as co-operate to research and join profession-related projects. Integrating problems and PBL into sustainability programs are applied in some universities, such as Arizona State University [12] and University of Saskatchewan [13].

Students benefit greatly from participating in PBL courses. Students engage and learn critical thinking and problem-solving skills throughout each step of the project. Moreover, soft skills could be developed as well [14]. PBL also has a great impact on English teaching, as students that learn English through PBL are more successful and have a higher motivation level than the students who are educated by the traditional instructional methods [15]. Even with the tendency to increase English 
communication skills for students, PBL can still be applied in content and language integrated learning (CLIL) or English as a medium of instruction (EMI). CLIL is an approach for learning content through an additional language (foreign or second), thus teaching both the subject and the language. EMI is the use of English to teach academic subjects in countries or areas where English is not the first language. Some undergraduate programs in Vietnam National University (VNU) are also taught under EMI and CLIL. Ai Ohmori [16] broadly indicates positive results in terms of student attitudes towards English language classes using a CLIL approach with PBL. Lastra-Mercado [17] outlines the connections between PBL and CLIL to suggest some theoretical implementations in the education framework.

In PBL, students should search more in the problem-space of authentic problems. By far, various technology scaffolds have been researched to understand how these tools support students. One recent strategy includes a "flipped classroom," when lectures are online and class time is spent engaging in active forms of learning. A study qualitatively investigated the implementation of a flipped classroom with PBL [18]. A flipped classroom, which is created from a blended learning model, emphasizes student-centered learning activities. Flipped classrooms, through the use of technology, have been proven empirically to improve student achievement [19]. The combination of PBL and a flipped classroom can be applied to a wide variety of subjects, from subjects in elementary or high school to graduate programs [20-23]. In these studies, this combination is likely to improve students' learning performance, and was significantly better than other teaching methods mentioned.

\subsection{From PBL to EPICS}

EPICS, an engineering design-based service learning and social entrepreneurship program, incorporates the engineering and human-centered design processes in providing solutions to real-world problems. With the same orientation, Cheryl et al. [24] desire to discover the relationship between the Interaction Design program and EPICS program at Purdue university. By focusing on students' experience, they identified several characteristics of a collaboration process via models. Different aspects of designers and engineers are useful to find differences between the two programs. The drawbacks of the research are that the product of an EPICS program is an industrial hardware, social facility, or practical result, while the output of design program is only a draft or sketch. They did not carry out a proposed model of interdisciplinary collaboration between the two programs. Jonathan et al. [25] discussed a brief story of an EPICS program in a computer science major and software engineering major of Butler university. Reseachers summarized the teaching experience, how to organize the class, and some theoretical projects that learners carried out. However, there are no conclusions, evaluating model, or technical achievements from this work. In References [26,27], teachers provide other views from high school about the EPICS program. They took advantage of acquirements in social activities to help communities. The results from this report is not validated in higher education, such as college or university, and is inappropriate for engineering.

In exploring the implication of this approach, Carla et al. [28] applied the EPICS model to develop learning through service-learning and community-based engineering. They found that this model effectively prepares learners for a wide range of careers more than teaching conventional engineering methods. More specially, it established and sustained a life-long relationship in the community by providing mutual advantages and considerable community impact. However, its contents must be updated and evolved continuously. Also, its scope should be expanded to pre-engineer learner or graduate student compared to the college or pre-college level of current research. On the research of added value from service-learning, References [29-31] introduced possible methods to measure when emerging project-based strategy and service learning took place in engineering education. It was recognized that the impact of the proposed approach of mixing quantitative and qualitative research on the knowledge, skills, attitudes, and attendance of participants are attractive to students, faculty, and employers. Via analyzing evidence, undergraduate students achieved superior cognitive levels in professional skills, industrial attitudes, and social outcomes. One of EPICS' characteristics is that it requires a multi-semester project. In this context, team members could be altered depending 
on unpredicted reasons. To appreciate the discretion of EPICS alumni, James et al. [32] investigated EPICS based on sequential mixed-methods study. They interviewed EPICS participants and conducted a thematic analysis of transcripts to explain how members related their EPICS experiences to the workplace.

In Vietnam, to connect between theories and practice, a technical festival named the Tech Show (http:/ / www.hcmut.edu.vn/vi/newsletter/view/tin-tuc/3445-tung-bung-ngay-hoi-ky-thuatbach-khoa-) is organized every year in Ho Chi Minh city University of Technology (HCMUT), Vietnam National University Ho Chi Minh city (VNU-HCM). On this occasion, students in many fields gather on campus to display their product range from technical solutions, useful devices, and applications in engineering. Professional practitioners, foreign enterprises, and research institutes also join the Tech Show. Positive feedback are given by employers to the school. Additionally, there are numerous challenges for first year students to fourth year students. In the first year, students must accomplish the mouse trap car in a mini-project of an introduction to engineering course, as in Figure 1. During this time, learners become accustomed to the technical design process, i.e., planning, drawing, reviewing, assembling, and testing. For last year students, they are able to join in the racing of a line-following car (http:/ / www.hcmut.edu.vn/vi/event/view/noi-san-bk/2972-chung-ket-cuocthi-lap-trinh-xe-dua-tu-dong-\%E2\%80\%93-bkit-car-rally-nam-2015). In this contest, they need to program a micro-controller to drive car that tracks the reference line. Theoretically, students have fundamental skills and knowledge to complete the tasks. Students' attitudes, interests, and active learning spirit remain unclear if they are taught in the conventional education approach.

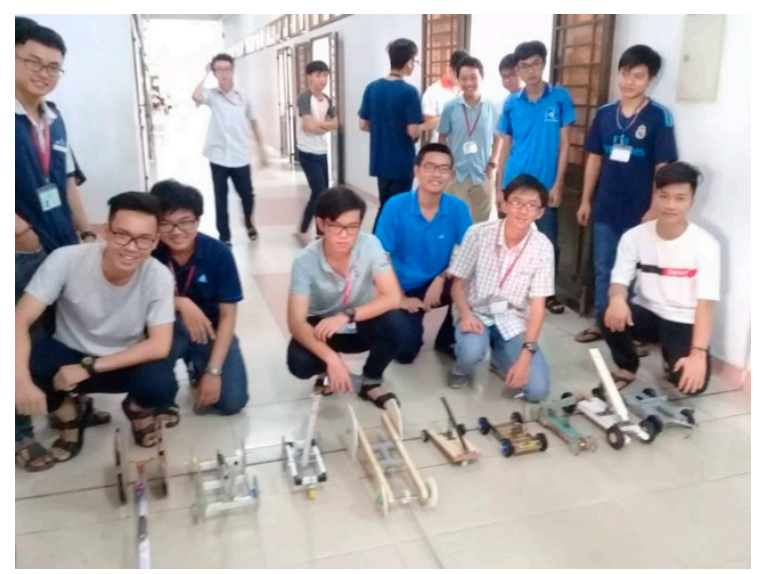

(a)

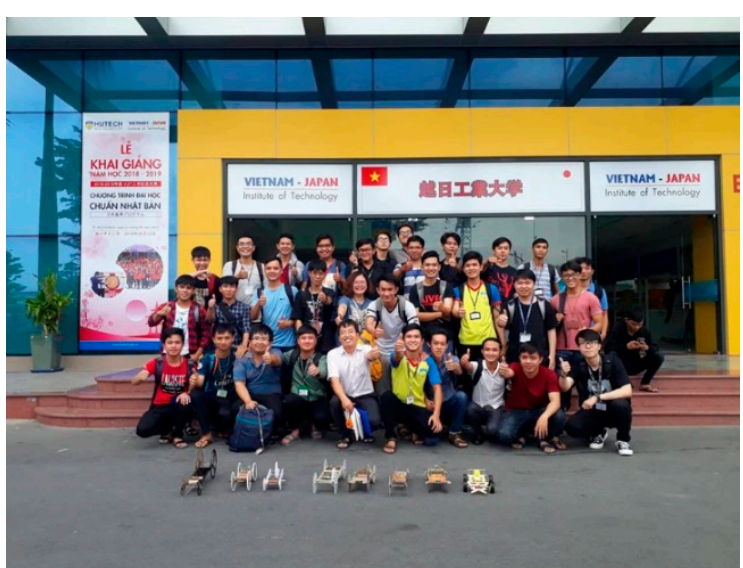

(b)

Figure 1. Mini-project of introduction to engineering class: (a) at HCMUT, and (b) at HUTECH.

\subsection{Logistics System and Handling Equipment}

Logistics deals with the planning and control of material flows and related information in organizations [33]. Logistics is one of the most important activities in modern societies. Logistics systems are made up of a set of facilities linked by transportation services. Facilities are sites where materials are processed, such as stored, sorted, etc. Logistics systems are made up of three main activities: order processing, inventory management, and transportation. Order processing is related to information flows in the logistics system and includes a number of operations. First, the orders requested by customers are transmitted and checked. After verifying the availability, the items in orders are retrieved from the stock, packed, and delivered along with their shipping documentation. Traditionally, it takes around $70 \%$ of the total order-cycle time for order processing activities. In recent years, it has gained much support from advances in electronics and information technology. Barcode scanning allows retailers to rapidly identify the required products and update inventory level records. As a result, the items' handling process is more accurate.

There is a lot of research about these handling systems. Whelan P.L. [34] suggested a material handling system that can be utilized for electronic component manufacturing, as well as crossdocking 
warehouse (for just-in-time distribution). A method and system for processing packages that is designated for special handling and notifying an appropriate party was introduced in the patent of Kadaba N. [35]. The method of automatically picking items to fill a purchase order supported a clear process from receiving an order to releasing the additional inventory [36]. References [37,38] introduced an inventory system including multiple mobile inventory trays with a positioning system that enables the mobile inventory trays to determine their three-dimensional coordinates and thereby navigate on factory floors. These inventions are the beginning studying and designing automation machines for material handling such as AGVs.

In 2002, Ito et al. [39] proposed an agent-based model for a warehouse system particularly for designing and implementing warehouse systems simulation with agents. Babiceanu et al. [40] focuses on the integration of the holonic-based control concept in the design of an automated material-handling control system. An important factor for implementing automation systems is to accurately identify the goods to be loaded and unloaded. Traditionally, printed labels that are easy to read are used. With e-commerce trends and automated handling system, RFID systems are being applied. A RFID-based resource management system (RFID-RMS) is designed to help users select the most suitable resource usage packages for handling warehouse operation orders by retrieving and analyzing useful information from a case-based data warehouse, which results in both time saved and cost-effectiveness [41]. They also developed and embedded a pure integral-linear programming model using a branch and bound algorithm to define the optimum travel distance for forklifts, which can be used for AGVs in warehouses.

\subsection{An Open Platform for Multidisciplinary Collaborations}

Mechatronics, which is composed of mechanics, electronics, and informatics, is one fundamental course for learners majoring in machinery. With the fast development of intelligent technologies and knowledge management, mechatronics needs to integrate with other fields, namely industrial management, to satisfy practical needs. The products of mechatronics must be combined with the others. One typical example of product in mechatronics is the autonomous vehicle. Ting et al. [42] launched the autonomous car as a topic in mechatronics education to cultivate successful engineers. Nonetheless, in this context, the global engineers require professional skills rather than the theoretical knowledge taught in mechatronics courses. They are compelled to co-work with other engineers. Team-work skills, practical techniques, and industrial application, which are not related to this course, becomes a must. With the same approach but different purposes, Hector et al. [43,44] want to apply a methodology using practical activities to determine the integration of different students whilst maintaining their interest in the learning process. In contrast, one team mentioned in this research includes students only in mechatronics. Over and above that, their output is only models, not practical products. Julio V. and Jose M.C. [45] present a low-cost platform for a robotics application in education. They use Raspberry Pi 3 as a main board, camera as a main sensor, and Gazebo simulator as a simulation tool. The difficulties of their works are that Raspberry Pi 3 seems to provide very slow computation for image processing while the camera calibration requires expertise. Also, the 3D printable components are not guaranteed to have the correct physical dimension. Pupils lack confidence regarding their ability to assemble the whole system. Last but not least, this project organized for first year or second year students is not applicable in the community.

It is rare to find a free framework for final students to practice the way to be an engineer. It is straightforward to find out an open robotics platform in the market. The famous branch name Lego offers different robotics kits in many versions (Mindstorms RCX, NXT, EV3, or WeDo). References [46,47] represent a platform that is open, low-cost, and easy to assemble for education and experiment. For the initial stage of students, these studies do not contain much technology. References [48,49] are discussed with respect to a robotics platform and teaching course. Some of them are from 3D printed parts, while the others are from an existing hardware system. However, the multi-disciplinary characteristics and collaborative spirit are not mentioned. In the other view, the results of References $[50,51]$ reveal 
a technique-based platform that is fit for professional researchers. The complex system and fusion data are combined to achieve excellent performance. In this paper, AGV, the symbolizing target of mechatronics, is chosen to be an open platform to develop in multi-disciplinary collaborations for final year students. Each undergraduate student in a specific area contributes his or her works toward the team's success. The collaboration among majors and multidisciplinary applications are validated in experimental discussion.

\section{Descriptions of Proposed AGV Model}

With the idea of multi-disciplinary applications, the platform should be developed, implemented, and expanded when connected to others. Both hardware and software support learners to enhance their self-development. In order to achieve the mission, an AGV-based structure is investigated with respect to the driving mechanism, appropriate size, load capability, feeding actuators, and line-following sensors.

\subsection{Design of an Open Hardware}

In Figure 2, the whole vehicle is shown as an overview of the structure. Basically, the robot can be divided into four sections: base layer, middle layer, feeder layer, and lifting layer. The base layer is to bear the body mass and the load. The linear slider leans on the middle layer to orientate the vertical direction. The feeder layer hangs rubber rollers to provide cargo automatically. The top, or lifting, layer is elevated using an electric cylinder and directly contacts the cargo.

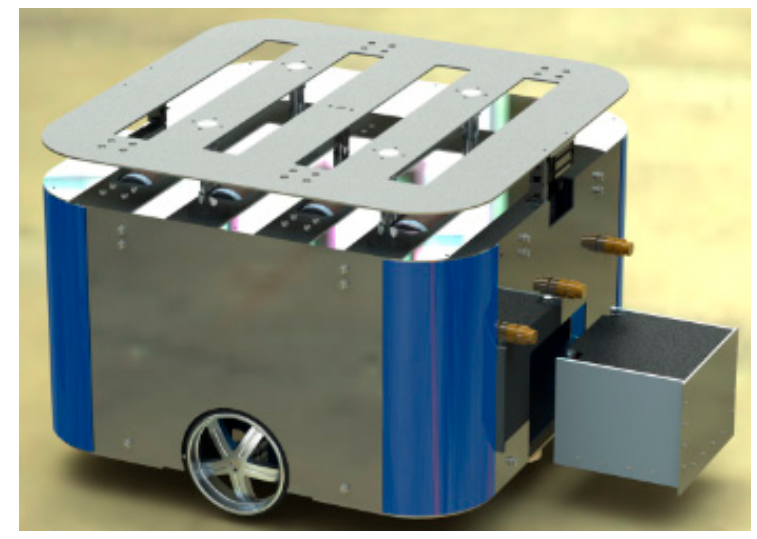

(a)

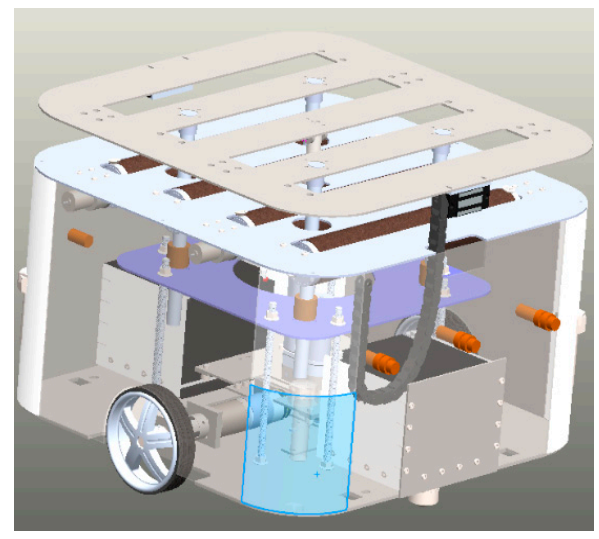

(b)

Figure 2. Overview of proposed autonomous vehicle: (a) outside view, and (b) inside view.

The driving mechanism consisted of two driving wheels on the side, with castor-type wheels in the front and back. In Figure 3, this structure avoids the slipping phenomenon, guarantees flexible motion, and all wheels are in contact with a certain surface. Two powerful motors were connected with shafts of wheels via gear boxes. The directional movement depended on the difference between the speed of the left wheel and the right wheel. The following path sensors were located at the center of the bottom layer, precisely at the front and the back to provide a bi-directional driving ability. Furthermore, the RFID reader module on this layer helped to navigate via tags, which were placed at each intersection. By reaching a crossroad, the vehicle read the identification numbers on the tags and returned to the host computer. Therefore, the server could track the path followed and generate the proper trajectory. 


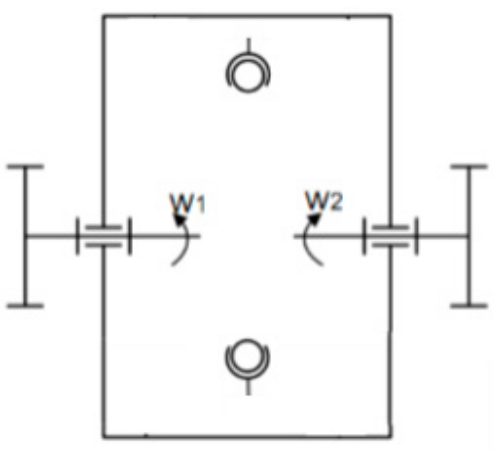

(a)

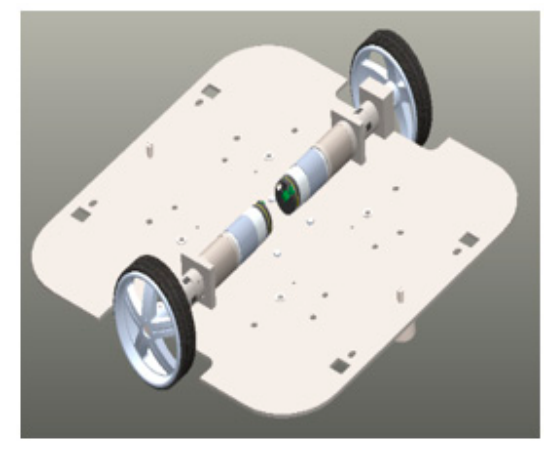

(b)

Figure 3. Driving mechanism on bottom layer: (a) theoretical design, and (b) 3D model.

The internal structure of the bottom of the vehicle is demonstrated in Figure 4 . The electric cylinder mainly provided a lifting force to elevate freight, while four slider actuators linearly preserved vertical balance. Under the electric piston, there was a loadcell to evaluate the weight level of goods. As a result, the automated vehicle was able to process proper control signals smoothly. Furthermore, it enhanced the advanced functions via the feeding mechanism. Whenever the mobile vehicle stopped at a destination, without human intervention, it automatically delivered freight to storage. In both the head and tail, the electromagnets were attached to lead the behind carriages. In this case, the overall vehicle-load played the role as a tractor-trailer system.

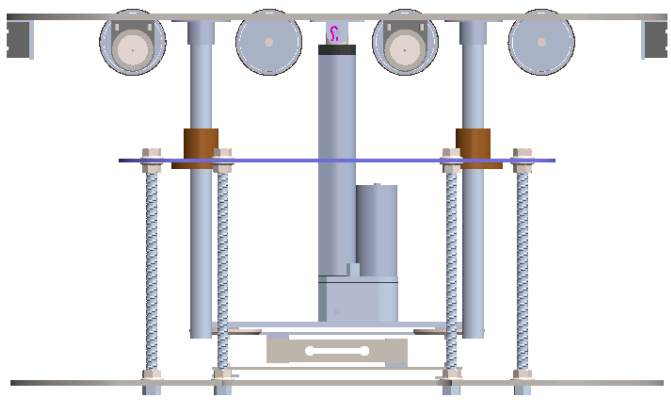

(a)

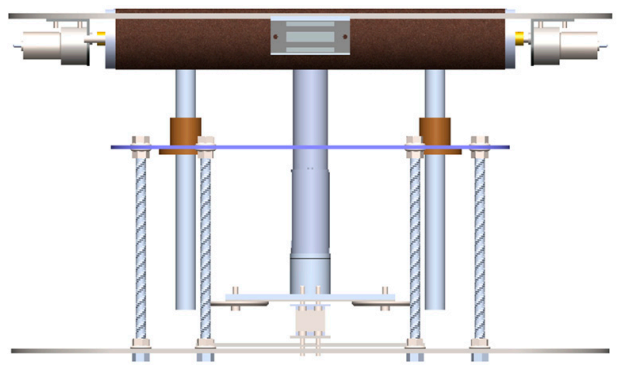

(b)

Figure 4. Inside architecture of loading and feeding mechanism: (a) side view, and (b) front view.

In this system, it was necessary to provide powerful management to process all of peripheral devices. In Figure 5, the connection diagram between the micro-processor and other components is illustrated. The high-performance ARM Cortex M4 32-bit operating at a max frequency of $168 \mathrm{MHz}$ is considered as the core of the CPU module. This embedded processor features a floating-point unit (FPU) single precision that supports all single-precision data processing instructions. Some key specifications, such as 1 Mbyte Flash, 192 Kbytes SRAM, three channels A/D 12-bit, and two channels D/A 12-bit offer a wide range of applications. The two DC servo motors with a power of $60 \mathrm{~W}$ and a max speed of $70 \mathrm{rpm}$ were able to drive the whole system. Due to the different speeds among servo motors, the autonomous vehicle can move easily and conveniently. There are several ways to track the reference trajectory. Generally speaking, using a line following sensor or magnetic tracking sensor are two popular methods. To enhance the competition of this system in the marketplace, a line following sensor turns out to be the best choice. The micro-controller could control an electric cylinder to lift cargo up or down with max load of $200 \mathrm{~kg}$. Moreover, this robot was equipped with electric lock which was capable of holding a powerful electromagnetic force to drive followers. Previously, human operators must stand at the start point and target location to pick up freights, which leads to high operating cost. In this design, the mobile robot will be run from the beginning to the end by itself. Thanks to roller actuators, the automated ability of the robot can be improved. 


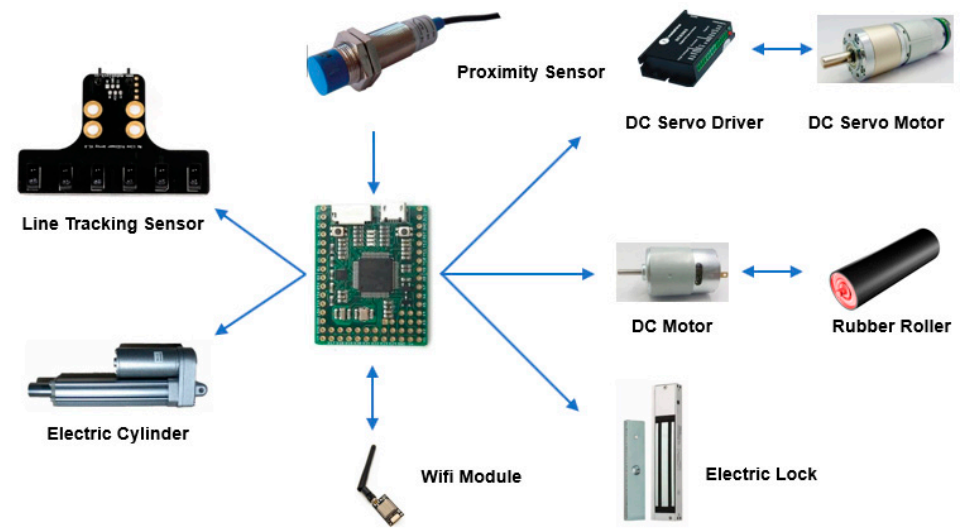

Figure 5. Block diagram of the control system in the proposed system.

The system coefficients and operating information are listed as Table 1 . The physical size was large enough to carry various loads while it still maintained the flexible execution. In some cases, the vehicle's suitable height helped it to move underneath shelves. Hence, it could work anywhere in the map regarding dimension. In industry, the working route consists of two kinds: uni-direction and bi-direction. To deal with numerous maps, in this work, the autonomous vehicle could move forward and backward. Furthermore, in some specific situations, such as material transportation in the textile industry, the robot extricates multiple shelves. As a result, the power of the motor and tires of wheels were studied to optimize selection. All electronics components were integrated on the mother control board as in Figure 6.

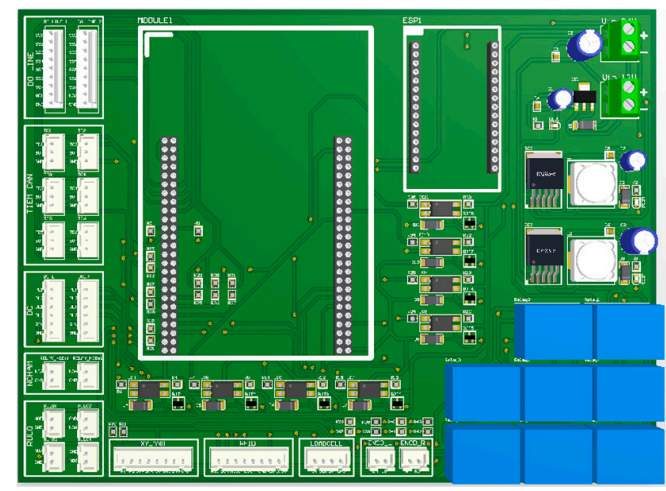

(a)

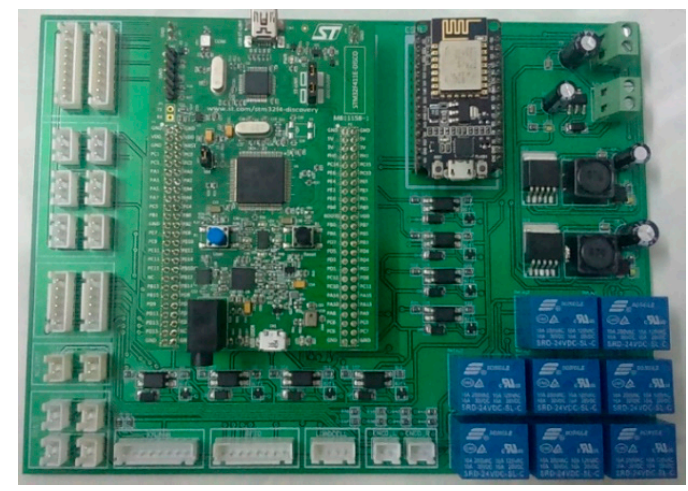

(b)

Figure 6. Simulation (a) and experiment (b) of control board in the project.

Table 1. Parameters and specifications of the system.

\begin{tabular}{cc}
\hline Item & Description \\
\hline Physical dimension & $650 \times 420 \times 350 \mathrm{~mm}$ \\
Wheels & $4(2$ driving wheels, 2 castor wheels $)$ \\
Max speed & $0.5 \mathrm{~m} / \mathrm{s}$ \\
Driving mode & Differential drive \\
Microcontroller unit & ARM STM32F405 \\
Power & 2 battery $12 \mathrm{~V}$ DC- 48 Ah \\
Tracking method & Line follower or magnetic sensor \\
Sensors & Loadcell, proximity, current \\
Carrying mode & Lift-up, trailer \\
\hline
\end{tabular}

\subsection{Design of an Open Software}

The main programming language chosen for this project was $\mathrm{C} / \mathrm{C}++$ because most students had studied $\mathrm{C} / \mathrm{C}++$ and the software components were written using applications in $\mathrm{C} / \mathrm{C}++$ as well. 
In Figure 7, the overall structure of the software level is explained in detail. Students could access and control hardware by using the open library. This library consisted of various Application Programming Interface (API) functions categorized into sub-classes, i.e., information (firmware date, type of robot), data (configurations, system parameters), motion (movement, stop), and monitoring (status, sensors). At the initial stage, the graphical user interface was provided to help beginners get acquainted with system. Later, at a higher level, students could customize the graphical user interface depending on their fields. For example, students in mechatronics major could attach more cameras, vibration sensors, or navigation sensors, while those in logistics were able to measure the efficiency of the imports and exports of warehouses. The library sent data to firmware to execute the autonomous robot. The method to control the DC motor is based on Pulse Width Modulation (PWM).

To support the students in programming, a set of API functions is recorded in Table 2. Relying on functional similarity, they were classified into sub-classes. When using this library, the user simply copied *.lib and *.dll into the project's directory. Later, referring to the header file, they just needed to program the syntaxes with the function's name. During the experimental tests, if the devices required calibration or they worked incorrectly, a standard graphical user interface in Figure 8 assisted students to overcome problems.

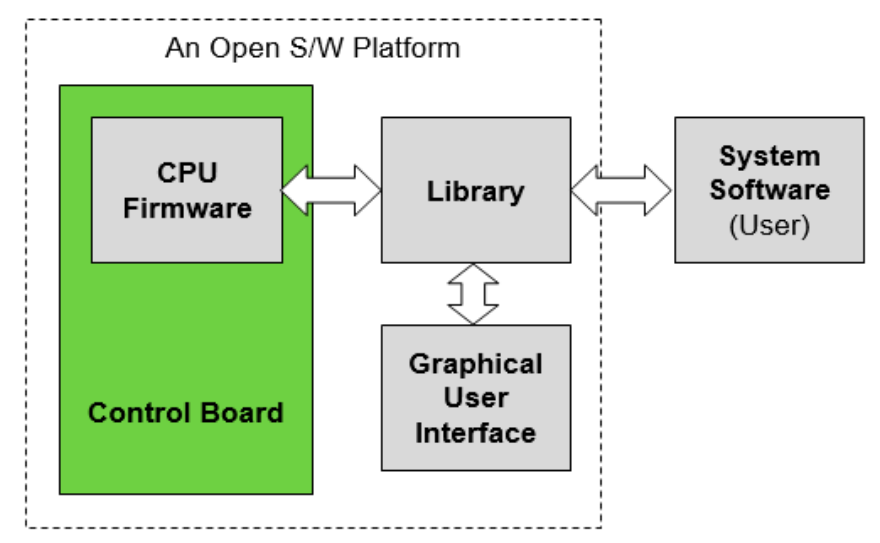

Figure 7. Flowchart of an open software (S/W) platform.

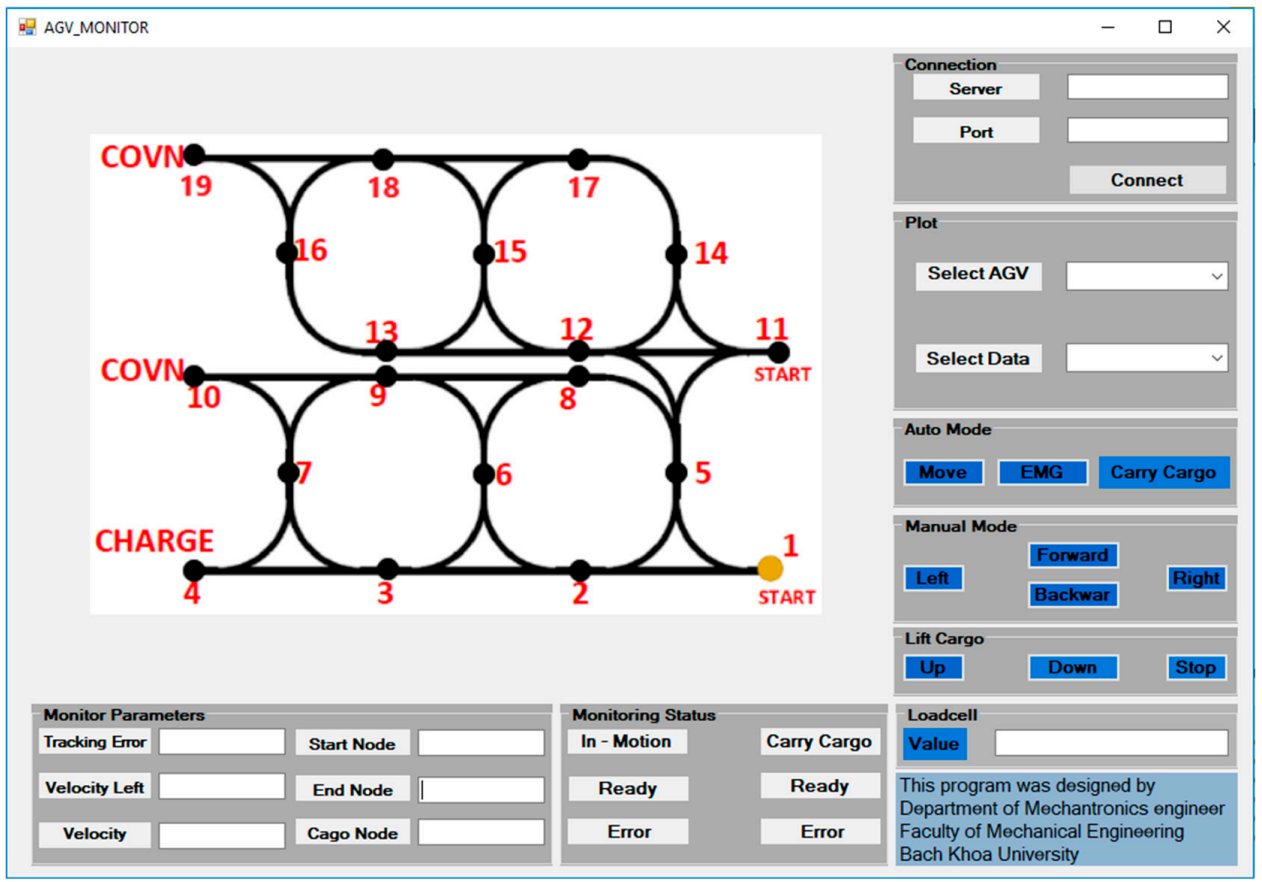

Figure 8. Graphical user interface of an open software platform. 
Table 2. List of API function groups.

\begin{tabular}{cc}
\hline API Group & Description \\
\hline Initialization & Initialize and setup connection in middleware \\
System parameters & Check whether status of connected devices is ready or not \\
Motion parameters & Establish parameters such as position, velocity, acceleration \\
Movement & Movement with absolute or relative mode \\
Status & Exchange data continuously while moving \\
Stop & Slow-down stop, emergency stop \\
Energy & Check status of battery \\
\hline
\end{tabular}

Figure 9 shows the architecture of the firmware including the supervising program and interrupt program. In Figure 9a, the host software in the computer reads the status of the channel and command and communicates with the firmware. Each status of the sensor, real position, and target position read from the variables of interrupt mode are provided to the host software. From the event control stage, the setting values of each item are checked and when the event occurs, the set of actions is controlled correspondingly. In Figure 9b, the interrupt had the cycle of $250 \mu$ s out of $4 \mathrm{kHz}$. In interrupt mode, the value of the encoder was read to assign the real position and each sensor status was also read. In previous sampling times, the calculated output value was generated for the actual movement of the motor. The real position read from the encoder was calculated for the real velocity. In the generator stage, if velocity changes were obtained from the equation of velocity, the amount of changing velocity would be added to the previous position to obtain the current target position. In the current sampling time, the known value of real position, i.e., the calculated value of output from the previous sampling time, was applied to match with the new calculated target position, then the control algorithm was used to compute the new value of the output. The newly calculated value was output on a real amplifier at the next sampling time. Depending on the need, the real position and target position were stored in a buffer. This provided function must be added in the host.

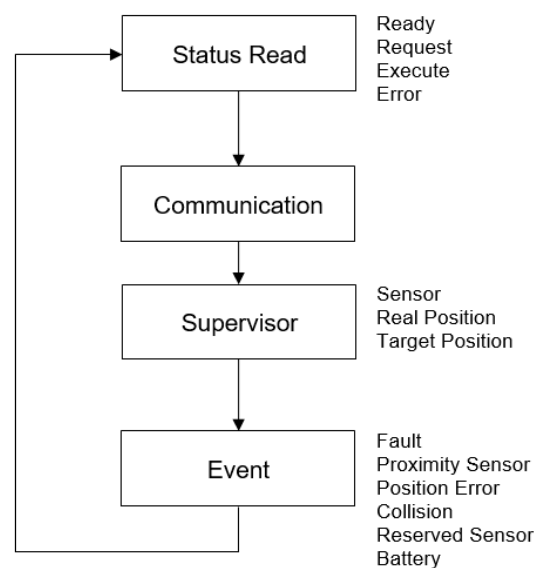

(a)

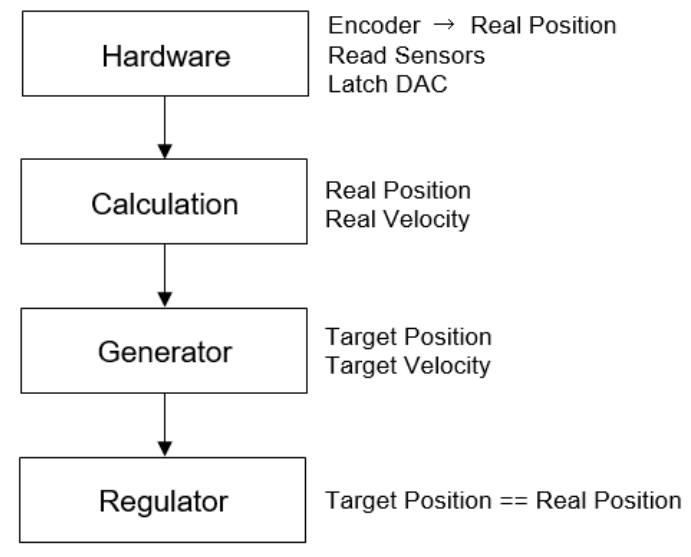

(b)

Figure 9. Flowchart in firmware: (a) background mode, and (b) interrupt mode.

\section{Case Studies}

To use the platform, it required users to build up additional hardware depending on their applications. In the most essential respect, this system accommodated the movement control by driving the left wheel and right wheel. The autonomous platform changed the directional movement with different velocities between the two wheels. The students stayed at the host computer to monitor the driving trajectory and control it as they desired. 
This open platform was used in the EPICS class that was based on PBL and the flipped classroom method for students from different programs working together to design the AGV. Therefore, the organization of classes is also described.

\subsection{Implementation of a Vision-Based Application}

Nowadays, the image processing approach has been applied in industry widely. The enterprise wants to employ an engineer with vision-based knowledge such that, by using digital cameras, the AGV must capture targets and track to follow human in the shared workspace. As a result, the teaching class should provide an opportunity for students to be familiar with image processing techniques. In this case, students designed the pan-tilt mechanism for two cameras (Figure 10) by themselves. The mechanical structure ensured that two cameras were stable, flat, and operated smoothly. They hung the pan-tilt structure on the autonomous vehicle's front side. Due to the cheap price of the camera, students examined the camera to find intrinsic and extrinsic parameters. To use the image processing techniques, an open source computer vision library called OpenCV (https://opencv.org/) was downloaded and installed. This tool offers functions such as cv2.calibrateCamera(objectPoints, imagePoints, imageSize[, cameraMatrix[, distCoeffs[, rvecs[, tvecs[, flags[, criteria]]]]]]) to calibrate parameters of the camera.

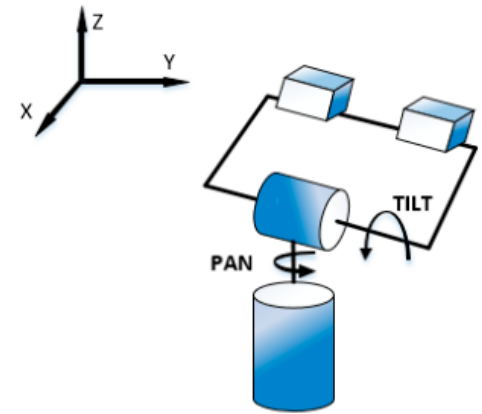

(a)

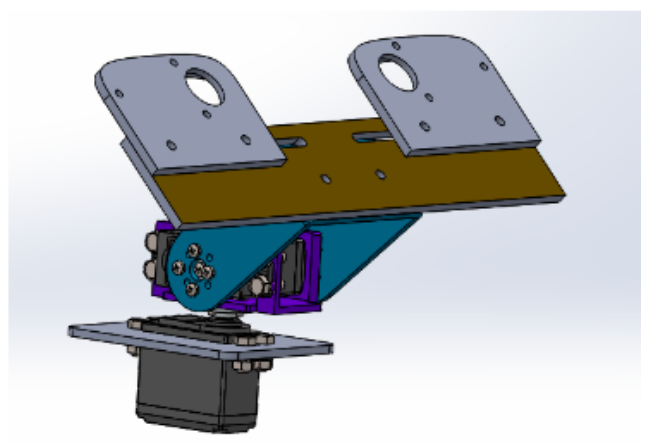

(b)

Figure 10. The pan-tilt mechanism for the digital camera: (a) theoretical design, and (b) 3D design.

Next, student calibrated the camera's system based on an epipolar geometry (Figure 11), a pre-processing stage to estimate the distance from camera to human. The purposes of sub-steps, consisting of stereo calibration and rectification were to discover a rotation and translation matrix between the two cameras and correct the epipolar line of images from cameras located in an axis.

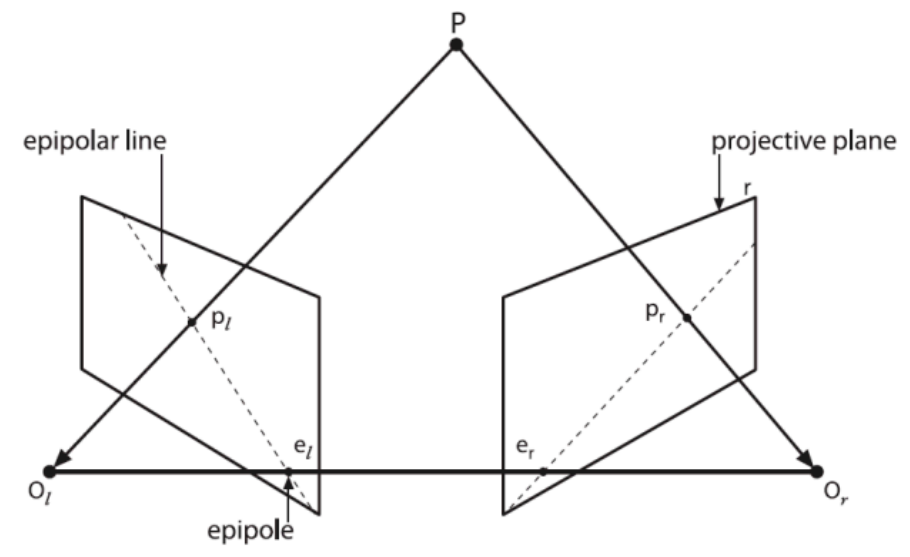

Figure 11. Epipolar plane in a dual-camera system. 
Basically, in the flipped class, students were taught to do four stages to gain information in 3D. First, the un-distortion was to reject the radial and tangential distortion due to computation. Then, the rectification was to output an image that was row-aligned (the same direction and location on the y-axis). Later, the finding of features between the left and right image helped to get the disparity of the object. Finally, from the disparity's results, it was easy to calculate the distance to a human, as in Figure 12.

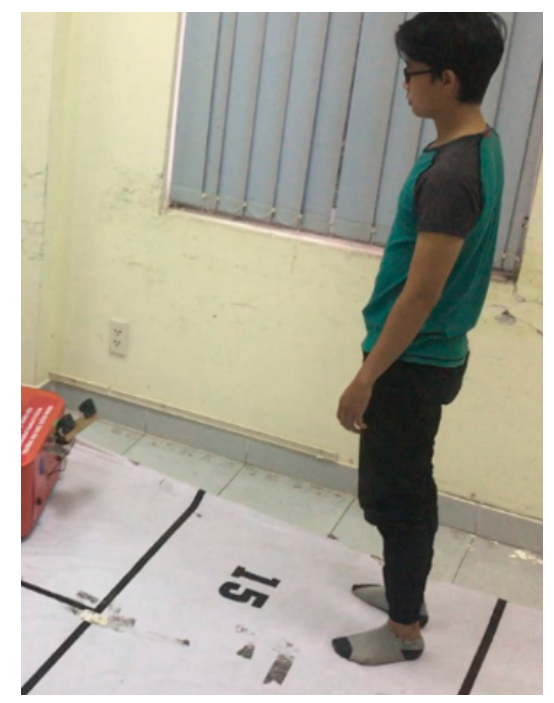

Figure 12. Experiment to estimate the distance statically by using digital cameras.

One of the simplest methods to recognize a target is to use the image threshold of image. Students captured the RGB picture and transferred it to an HSV (Hue, Saturation, Value) format. The dilation and erosion operators assisted in obtaining a smoother image, as in Figure 13. To tie the boundary pixels, edge linking algorithms, for instance, contour tracing, were suggested. During the procedure, the capturing time and processing time from the camera ought to be synchronous. In order to decrease the asynchronization error, the parallel programming, which included multi-thread in Python, was implemented on the computer. The results of the image processing stage were to deliver data for the automated guided vehicle to track a target, as in Figure 14. For convenient control, a group of students designed a graphical interface (Figure 15) by using the API functions in this paper.

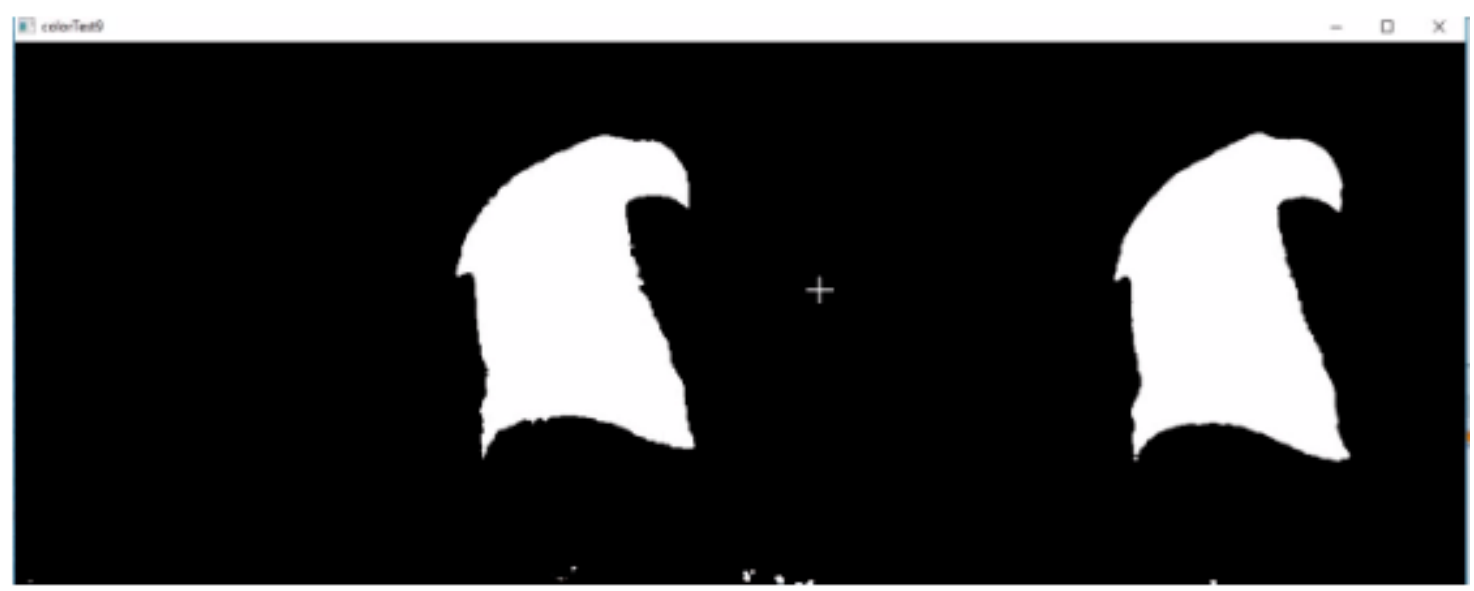

Figure 13. Image after threshold in HSV. 


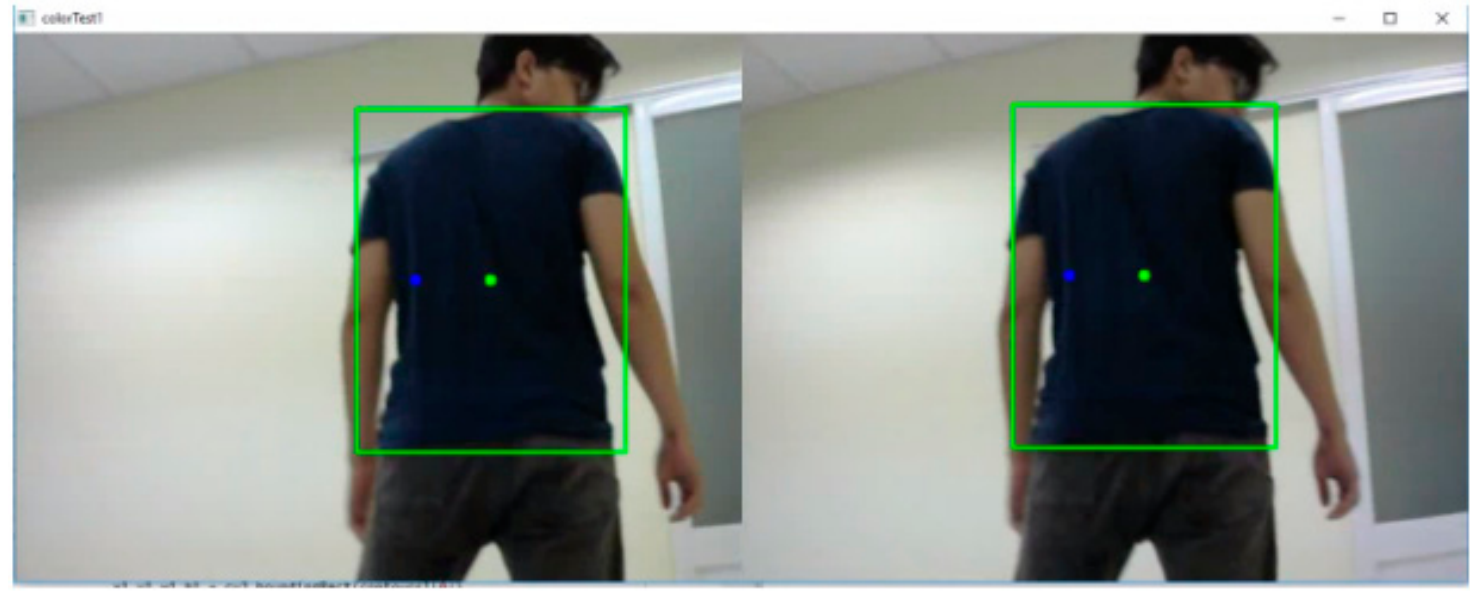

Figure 14. Experimental image that students obtained from digital cameras.

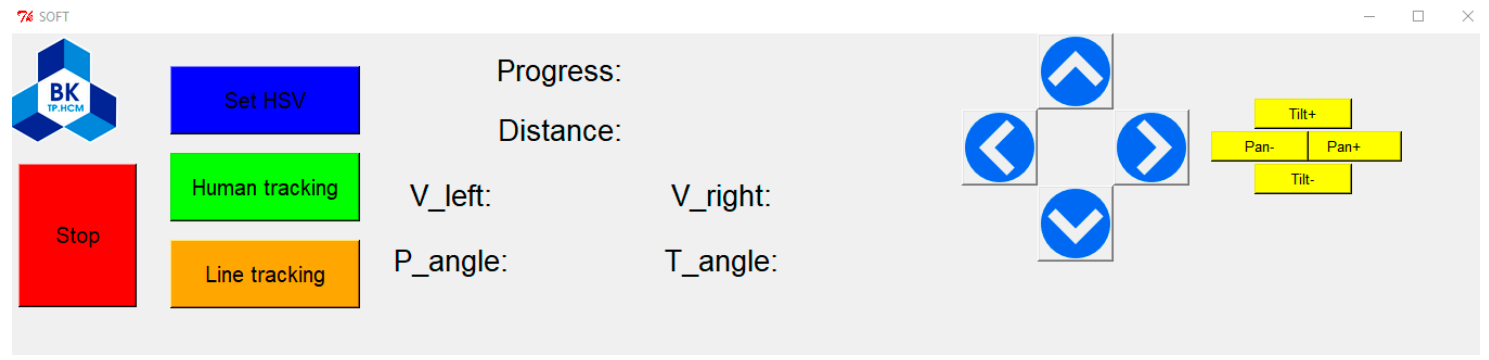

Figure 15. Student-designed interface by using the API functions in the computer.

\subsection{Implementation of Control Application}

From experiments, undergraduate students acknowledged that the total loads put on the shelf were unknown in advance. On the other hand, in a conventional case of programming, there was no difference among test cases (no load, light load, medium load, full load) in operating mode. Some of them recommended that it was compulsory to implement an intelligent algorithm to distinguish the control signal depending on current status of the load. The loading mechanism for the load cell is demonstrated in Figure 16. Additionally, the control scheme needed to keep the tracking error converge to zero as the autonomous vehicle followed the reference trajectory. The intelligent controller was selected using fuzzy logic under the instructor's guide. In Figure 17, the inputs of fuzzy control were load and tracking error, while the outputs were the control signals to the left and right wheels. This meant that the driving strategy of vehicles relied on the load mode and current following error. In Table 3, the fuzzy rules are established in the sense that, for example, if the load was light and the vehicle deviated on the left side too much, then the fuzzy controller drove max speed on the left wheel and at a much lower speed on the right wheel.

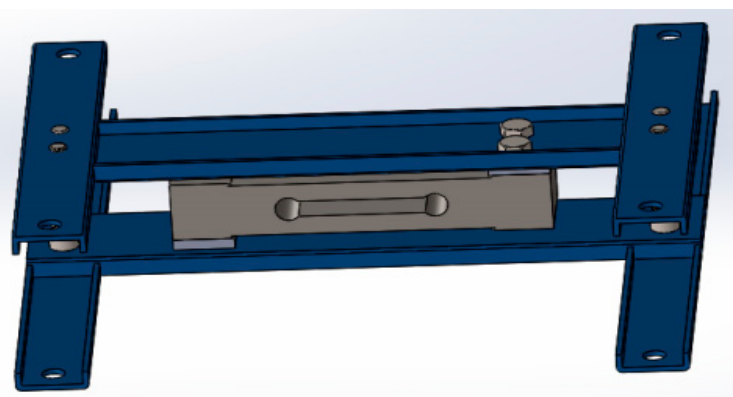

(a)

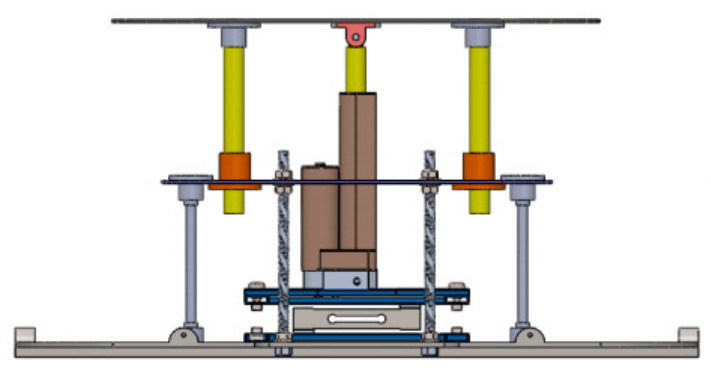

(b)

Figure 16. Design of attaching mechanism for load cell (a) and loading actuator (b). 


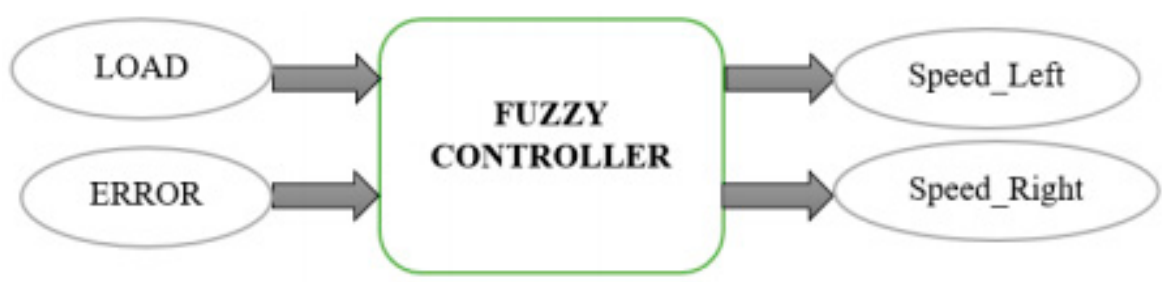

Figure 17. Structure of proposed fuzzy controller.

Table 3. Table of rules in fuzzy sets.

\begin{tabular}{cccccc}
\hline Load & EL & L & MID & R & VR \\
\hline \multirow{2}{*}{ Light } & L-MAX & L-VF & L-N & L-SL & L-VL \\
& R-VL & R-SL & R-N & R-VF & R-MAX \\
Medium & L-VF & L-F & L-SL & L-VL & L-VL \\
& R-VL & R-VL & R-SL & R-F & R-VF \\
Heavy & L-F & L-N & L-VL & L-VL & L-SL \\
& R-SL & R-VL & R-VL & R-N & R-F \\
\hline
\end{tabular}

In Figures 18 and 19, most of membership functions are triangular shape and trapezoidal shape because students were familiar with them. In fact, following the instructor's guide, undergraduate learners were able to complete programming in a short amount of time. The sampling time set up in the micro-controller was $500 \mu$ s to guarantee the real-time performance. To deal with the short cycle period, the fast computation consisting of singleton outputs was more relevant.

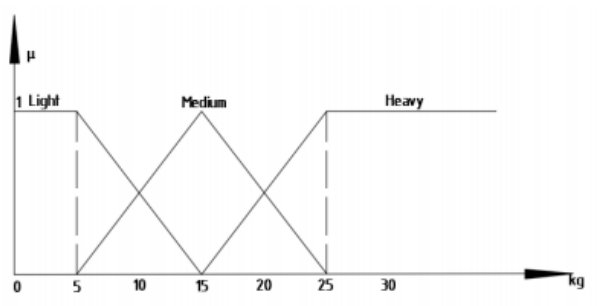

(a)

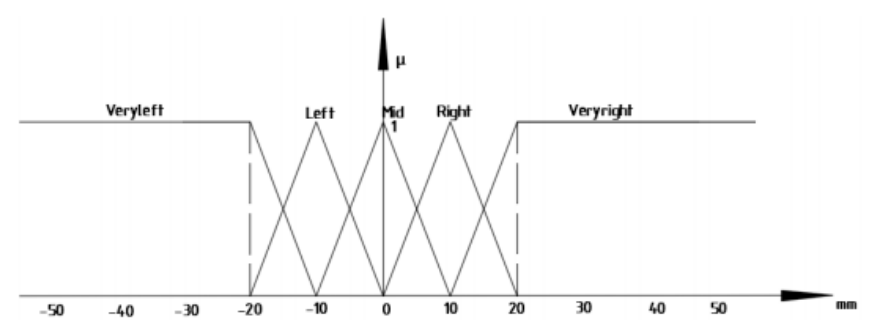

(b)

Figure 18. Input membership functions: (a) load, and (b) tracking error.

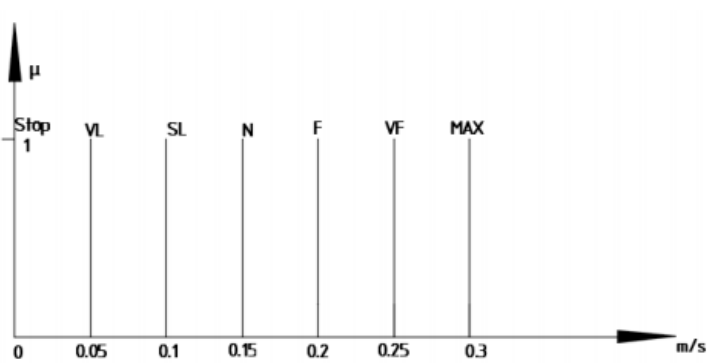

(a)

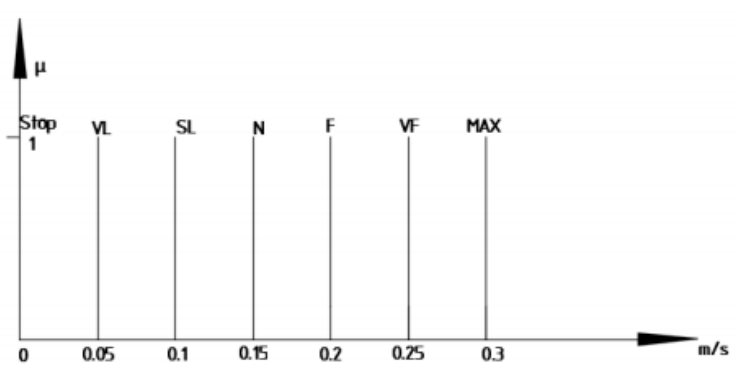

(b)

Figure 19. Output membership functions: (a) speed left, and (b) speed right.

The test scenario was planned as given in Figure 20. Initially, the AGV would stay at the start point in a ready status. After the command was released, the host computer scheduled the reference trajectory from the start point to the end point. The cargo or load was located at point $C$ where the AGV travelled. Moving with an unknown load was a good lesson for students in control application. It must keep tracking the following line while keeping the cargo steady. The AGV completed a given task whenever it moved to the end point with the load. Students attained the data in off-line mode and plotted it using Matlab software (R2014a version, MathWorks, Natick, MA, USA), as in Figure 21. 


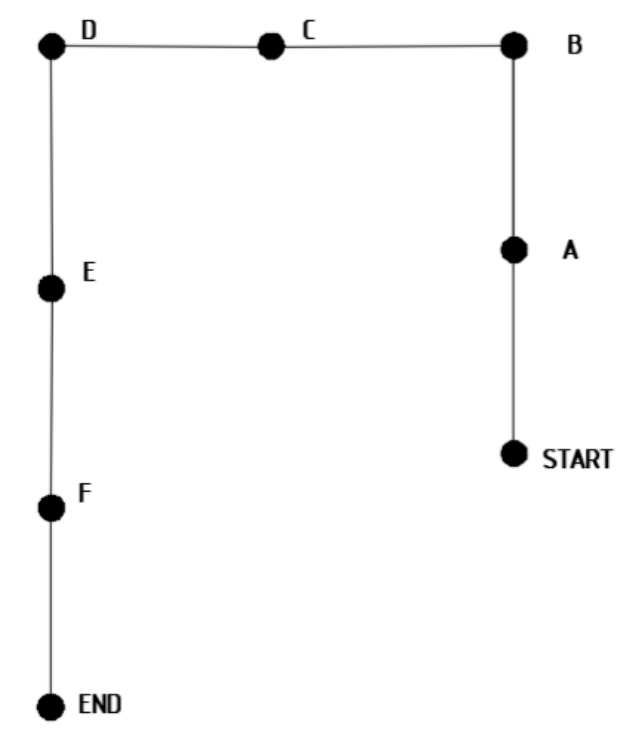

Figure 20. Reference trajectory in the test case.

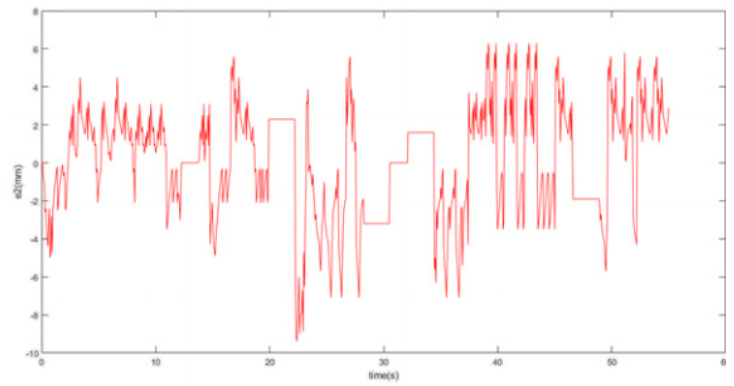

(a)

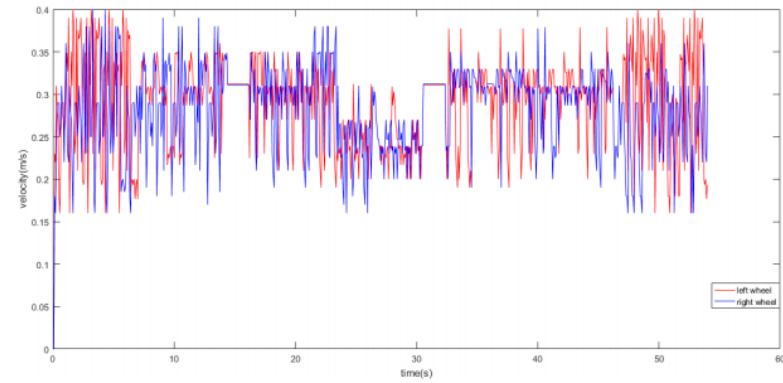

(b)

Figure 21. Experimental results that students obtained: (a) tracking error, and (b) speeds of wheel.

\subsection{Implementation of Logistics Application and EPICS Course}

The combination of third and fourth year students of Mechanical Engineering, Mechatronics, Computer Engineering, and Industrial Systems Engineering in the EPICS class began in early 2018 in the BUILD-IT project under the mentoring of lecturers from the University of Arizona, one of the schools that successfully implemented the EPICS class model. This was a course with the assessment based on tangible products and students completed six stages. As a pilot class, there were approximately 20 student groups from 4 universities for the first time and 30 groups from 6 universities for the second time. The lead lecturers of the class were from the Department of Mechatronics and Department of Industrial Systems Engineering, along with support from lecturers in other departments. Lecturers played an instructing role in the process, organizing group activities, guiding assessment, and commenting on every step in class hours. Students needed to work in teams outside the class, learn the relevant knowledge by themselves (from an open platform and flipped classroom documents or videos), and discuss and implement the model design and fabrication steps. After two EPICS classes, students excitedly learned necessary specialized knowledge for their needs. The student groups knew how to divide the work based on the strengths and weaknesses of each member. Students responded well to the learning outcome of the course and the program outcome of the Accreditation Board for Engineering and Technology (ABET) criteria. It was found that the model proposed in this paper was very successful.

The six stages of EPICS included: (1) project identification, (2) specification development, (3) conceptual design, (4) detailed design, (5) delivery, and (6) service maintenance. There were too few class hours to guide the content of course in detail, so the theory lesson for each design 
stage was uploaded to Google classroom or the LMS (learning management system-Moodle) of our University. For example, Stage 1 included: conduct a needs assessment, identify stakeholders, understand the social context of your community partner, define basic stakeholder requirements, and determine time constraints of the project. The document of these theory lesson included the definition, implementation method, or support tools. Oriented questions and suggestions for implementation processes were also introduced. Specific examples were provided. The checklist was also available for groups to self-assess the process.

In addition to the course's six-step design process, specialized logistic and AGV knowledge on design and fabrication tools were implemented. The logistic system's lesson included two main issues of logistics: warehouse and transport. Transport is used to determine the locations of warehouses or distribution centers and the selection of transport modes, as well as vehicle and resources schedule. The warehouse's lesson provided the theory of warehouse models and decision-making issues in the warehouse from design to operation. The handling equipment was also listed in terms of its characteristics, effects, and deployment conditions. The activities of loading and unloading that related to the AGV was described to help students understand the current situation or its operations in a warehouse. The required operational parameters of AGV that related to goods transportation in a warehouse were also introduced. For each group of students, the warehouse model was selected to propose the requirements of AGV's operational parameters. This affected their AGV's design and fabrication. The supported resource for AGV's design and fabrication were presented in the previous section.

In this course, each student had a unique role to lead the team depending on their background knowledge and the remaining members supported the leader. For example, with the first two phases, it was necessary to identify the needs of the system in general and in the logistics system in particular, where the Industrial Systems Engineering students lead the group. The analysis and conceptual design phase was lead by a Mechatronics student. The detailed design stage and delivery stage was be the primary responsibility of the Mechanical Engineering or/and Computer Engineering students. The test and evaluation step of the system (service maintenance), as well as the writing of the report by English, was done by all of the team members. In each stage, every member should understand basic knowledge, so it was important to have the open source for those who were in charge of each stage to explain to the remaining members. Therefore, students could learn, discuss, survey, measure, design, fabricate, and evaluate the group's products.

\section{Discussion}

The open platform described in this paper for the multi-disciplinary approach was proposed to surpass the existing limitations of the traditional educational method. From the authors' experiences, a student-centered view is one of the best training methods nowadays. By merging the idea of PBL as a teaching method in a class that was organized by EPICS, the interests of student in learning, professional skills, effective cooperation, and confidence were enhanced significantly as compared to traditional classes. To validate the effectiveness of the proposed approach, we analyzed both direct tools and indirection tools. For direct ones, it was agreed that reports, exercises, oral discussions, and seminars were to be used to carry out rapid reflections from students. We collected data from the beginning lessons to the end of the course. In our research, the final showcase and interview were judged as indirect measuring methods by means of the program manager, stakeholders, students, and board of referees. We believe that our results reflected the effectiveness, feasibility, and reliability of the proposed approach.

\subsection{Direct Measurements}

Unlike the traditional course where there is only a paper exam at the end of the semester, we used the various tools as Table 4 to assess the student's performance during the class. Several detailed evaluations and activities are provided in Tables A1-A3. From the view of success in the EPICS class, students were required to possess professional skills, for example, engineering skill, soft skill, and 
management skill, through many kinds of evaluation. Their own a depth knowledge of mechatronics and programming, and the ability to synthesize related information to apply what they learnt was also examined. They also gained experience in timing management, scheduling process, communication, and discussion. Above all, the program brought self-confident and learning interest for students after graduation. The authors believe that in the initiative stage of EPICS in Vietnam, the class was more successful than expected, at least in the contributed awareness of engineers in the community. In addition to conventional lectures in mathematics, physics, mechanical design, or operations research, it was helpful for undergraduate students to prepare their careers in our society when they joined in an EPICS class.

Table 4. Lists of direct assessment tools.

\begin{tabular}{|c|c|c|}
\hline Item & Description & Achieved Skill \\
\hline Weekly report & $\begin{array}{l}\text { Every week, students reported a progress of work to } \\
\text { instructors. This kind was similar to a short project report }\end{array}$ & $\begin{array}{l}\text { Planning, time management, } \\
\text { design skill, writing skill }\end{array}$ \\
\hline Technical report & $\begin{array}{l}\text { Whenever students met problems in their project, the } \\
\text { reports of understanding techniques, discussion, } \\
\text { recommended solutions and saving experiences in future } \\
\text { are proposed }\end{array}$ & $\begin{array}{l}\text { Ability to refer engineering tools } \\
\text { to solve, teamwork, synthesizing } \\
\text { skill, technical thinking }\end{array}$ \\
\hline Presentation & $\begin{array}{l}\text { A multislide show was organized based on team jobs to } \\
\text { share knowledge with others }\end{array}$ & $\begin{array}{l}\text { Self-confident, speaking skill, } \\
\text { interpretative skill }\end{array}$ \\
\hline Oral survey & $\begin{array}{l}\text { Each team met stakeholders, users, and operators in } \\
\text { community to enhance the design }\end{array}$ & $\begin{array}{l}\text { Communication skill, social } \\
\text { interface, design process }\end{array}$ \\
\hline Peer evaluation & Each member in the team should assess their friends & $\begin{array}{l}\text { Self-evaluated skill, team } \\
\text { management }\end{array}$ \\
\hline
\end{tabular}

\subsection{Indirect Measurements}

To gain the objective feedback, our teams joined in the EPICS showcase, as in Figure 22, after completing the program. In this exhibition, teams were evaluated according to the EPICS final showcase competition rubric, as in Figure 23. The following were worthy of note:

- $\quad$ Overall quality of the proposed model: the products of the project were of a moderate quality in terms of both technique and academic knowledge. Teams verified an understanding of EPICS design process, faced challenges, and solved them. Each member needs to collect data from the logistics warehouse, interview workers, and record their opinions. The results were delivered to stake-holders to apply in their business. Furthermore, teams were willing to co-operate with others to widen their projects' applications.

- $\quad$ Team's demonstration: the explanation in systematic design was confirmed to obey the six stages of the design process of EPICS (project identification, specification development, conceptual design, detailed design, delivery, service maintenance, redesign, and retirement).

- Team's ability: in this case, the team answered questions related to the project directly while they were at the site. Although they lacked the experience of a crowd, it required substantial effort to accomplish.

- Quality of design review: the presentation (involving visual information) focused on the design process was highly evaluated.

Moreover, an evaluation report was developed based on the data collected via the end-of-course and post-event survey tailored to the programming and the curriculum of the EPICS course. The survey was designed to collect lecturers' and students' feedback on their overall experience and the EPICS course contents. The survey was administered using a Qualtrics web link. The language settings of the survey were both English and Vietnamese. The survey questions were designed in English and translated into Vietnamese by the organizers. 


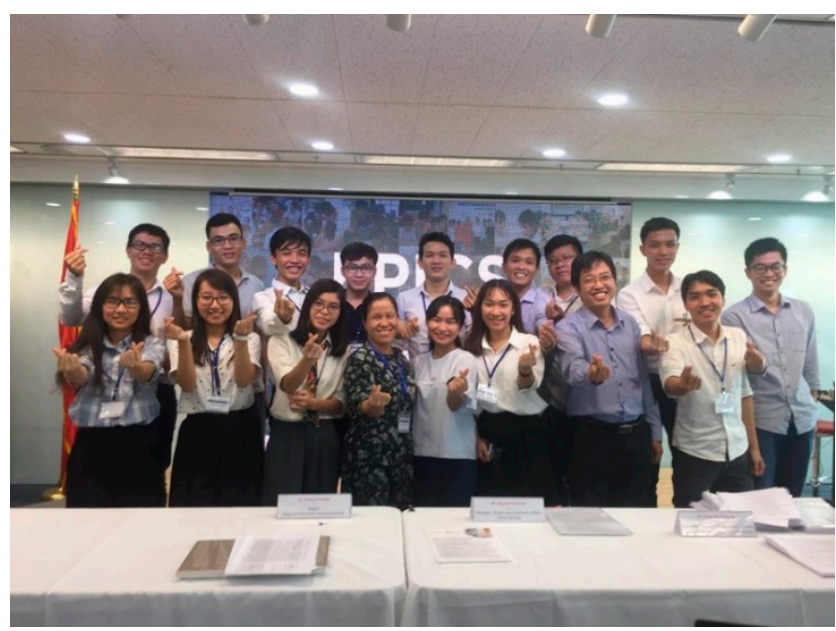

Figure 22. Students in EPICS Showcase lead by Dr Thinh and Dr Ha.

Overall quality of the project given its stage in the design process:

- The project design or concept is technically sound and feasible

- Level of detail demonstrates an understanding of the design issues, challenges and constraints

- Safety, maintenance and service issues have been addressed in the design

- Project design was aesthetically pleasing

- Curiosity: the team showed initiative exploring new areas of information

- Connection: Has the team drawn from non-engineering sources to inform their design? (i.e.: customer discovery, researched economic data associated with project, user feedback, etc.)

- Creating value: The team has articulated the value the project can/could deliver to its user and/or community partner

Team's Demonstration of the Design Process:

- User-centered issues are addressed

- Team demonstrates effective communication with community partners and other stakeholders

- Team demonstrates a systematic approach to evaluating design alternatives and making design decisions

- Team demonstrates appropriate flexibility in thinking about the design

Team's Ability to Explain the Project and Answer Questions:

- Team communicated the context and the scope of the project effectively and appropriately

- Team's answers were clear, succinct, and engaging

Quality of the design review presentation:

- Information communicated visually was well organized and relevant

- Team members participated and presented themselves in a professional manner

- Team members were dressed appropriately

- The presentation facilitated constructive feedback as a reviewer

Figure 23. EPICS final showcase competition rubric. 
Fifty-three participants of the EPICS final showcase completed the survey, which made up a response rate of $48.6 \%$ (53 out of 109). The large majority of those who participated in the survey were students and that made up $81 \%$ of the total. Approximately $12 \%$ of the respondents were from universities; specifically, $6 \%$ were faculty members (lecturers, senior lecturers), $4 \%$ were university leaders (Rector/Vice Rector, Dean/Vice Dean, Head/Deputy Head of Department), and 2\% were other university personnel (e.g., administrative staff). Meanwhile, those who worked for business/industry and those who worked for government shared the same percentage at $2 \%$. The rest of the respondents $(2 \%)$ were other non-university personnel. The summary of the survey's results is present in Table 5.

Table 5. Table of survey's results.

\begin{tabular}{|c|c|c|c|}
\hline \multicolumn{2}{|r|}{ Finding About } & \multicolumn{2}{|c|}{ Percent of Those Surveyed } \\
\hline \multirow{2}{*}{$\begin{array}{l}\text { Faculty's overall } \\
\text { satisfaction about }\end{array}$} & course materials and supplies & $80 \%$ & \multirow{2}{*}{$\begin{array}{l}\text { satisfied and very } \\
\text { satisfied }\end{array}$} \\
\hline & classroom facilities and equipment & $67 \%$ & \\
\hline \multirow{4}{*}{$\begin{array}{l}\text { Faculty's evaluation on } \\
\text { contribution of the } \\
\text { EPICS course to student } \\
\text { development }\end{array}$} & an awareness of the customers & $100 \%$ & \multirow{4}{*}{$\begin{array}{l}\text { Somewhat useful } \\
\text { and very useful }\end{array}$} \\
\hline & $\begin{array}{l}\text { an ability to collaborate with people from other disciplines and develop } \\
\text { an appreciation for cross-disciplinary contributions from individuals }\end{array}$ & $100 \%$ & \\
\hline & $\begin{array}{l}\text { an appreciation of the role that their discipline } \\
\text { could play in social contexts }\end{array}$ & $100 \%$ & \\
\hline & $\begin{array}{l}\text { enhance the ability to identify and acquire new knowledge as a part of } \\
\text { problem-solving/design process }\end{array}$ & $67 \%$ & \\
\hline \multirow{2}{*}{$\begin{array}{l}\text { Students' overall } \\
\text { satisfaction }\end{array}$} & quality of team activities & $80 \%$ & \multirow{2}{*}{$\begin{array}{l}\text { satisfied and very } \\
\text { satisfied }\end{array}$} \\
\hline & course duration & $73 \%$ & \\
\hline \multirow{5}{*}{$\begin{array}{l}\text { Contribution of the } \\
\text { EPICS course to student } \\
\text { respondents' } \\
\text { professional } \\
\text { development }\end{array}$} & understanding of design as a start-to-finish process & $95 \%$ & \multirow{5}{*}{$\begin{array}{l}\text { Somewhat useful } \\
\text { and very useful }\end{array}$} \\
\hline & an awareness of the customers & $86 \%$ & \\
\hline & $\begin{array}{l}\text { an ability to collaborate with people from other disciplines and develop } \\
\text { an appreciation for cross-disciplinary contributions from individuals, }\end{array}$ & $81 \%$ & \\
\hline & an awareness of professional ethics and responsibility & $86 \%$ & \\
\hline & $\begin{array}{l}\text { an appreciation of the role that their discipline } \\
\text { could play in social contexts }\end{array}$ & $95 \%$ & \\
\hline \multirow{5}{*}{$\begin{array}{l}\text { Student respondents' } \\
\text { perceptions of } \\
\text { preparedness }\end{array}$} & $\begin{array}{l}\text { identifying and acquiring new knowledge as part of } \\
\text { problem-solving/design process }\end{array}$ & $95 \%$ & \multirow{5}{*}{$\begin{array}{l}\text { Somewhat prepared } \\
\text { and very prepared }\end{array}$} \\
\hline & $\begin{array}{l}\text { applying professional ethics and responsibility } \\
\text { in multidisciplinary projects }\end{array}$ & $95 \%$ & \\
\hline & $\begin{array}{l}\text { enhancing oral and written communication skills } \\
\text { in multidisciplinary design projects }\end{array}$ & $95 \%$ & \\
\hline & $\begin{array}{l}\text { applying disciplinary knowledge and skills to real } \\
\text { and ill-defined problems }\end{array}$ & $92 \%$ & \\
\hline & providing services and solutions to address the needs of the community & $92 \%$ & \\
\hline
\end{tabular}

While the final showcase competition took place, a discussion with the director program, learners, faculty, and stakeholders was propounded in the interview of VTC10 channel [52]. We now illuminate achievements from EPICS students in correlation with other students. In the director's speech, it was stated that young students wished to join in activities for community. They discovered social problems of neighbor groups and actively understood difficulties in their environment. From knowledge in 
school, they hoped to suggest practical solutions to overcome these. In other words, undergraduate students improved their social awareness and ethics.

"In my perspective, the application of technical knowledge for serving the community is absolutely suited Vietnam, because Vietnam has young and active population, they crave to participate in solving community's issues for the future of Vietnam. More and more the youth join in community serving activities, which is highly positive. What important is to understand the problem and put your heart and soul into it." Mr Michael Greene, USAID/Vietnam mission director.

In the view of the country director, she supposed that learners were able to create creative and useful ideas to contribute to the community. More and more closed relationships between students and people were consolidated. Likewise, students could be trained with professional preparation, systems thinking and design process skills that are matched with EPICS learning outcomes.

"Students don't have to wait for graduation to be able to start their career. Right now, they can create something different and contribute to the society, especially helping their community to solve problems. I think this is a meaningful and interesting program. It's not just about education but also helping them find out solutions to such a problem. They have been working directly from the first stage of problem identification to the final stage of analyzing and solving it." Ms Phuong, country director, Arizona State university.

To measure what EPICS students learnt, their responses after they completed the course have been recorded. One student mentioned that starting from ideas, she discovered how to bring it to reality. A second student gained direct connection with community via interviews and interaction to update the design. As a result, the gap between theory and practice was decreased. Another student thought that communication, teamwork, discipline knowledge, broader context, and multidisciplinary design techniques are obtained when learners participated during the process of EPICS.

"This is a new program. We have learnt a lot from it and we can bring our ideas to life." -First student

"Here we have the opportunity to practice and to be creative, to have direct contacts with the community to interview and interact with people so as to find the right solution, and to develop a project to create something useful for our society." —Second student

"Firstly, the contest is sponsored by Arizona State university. All documents are written in English so I can develop my English skills, one of the most important skills for students. Secondly, I want to develop design skill because it is a must-have skill to serve the community. One more thing is that I want to learn soft skills, teamwork skills in the process of participating in the contest." -Third student

Finally, the comparison results between EPICS students and other students are illustrated in Table 6. They were appreciated in terms of three rating levels in the aspects of social perception, multidisciplinary design, specialized knowledge, and community-based responsibility. It can be seen that EPICS students were fully aware of practical engineers in the global community and well-prepared for their careers in future.

Table 6. Comparison between EPICS students and other students in three levels (good, fair, medium).

\begin{tabular}{ccc}
\hline Learning Outcomes & EPICS Students & Other Students \\
\hline Community awareness & Good & Medium \\
Multidisciplinary design & Good & Medium \\
Social entrepreneurship & Fair & Medium \\
Design process & Good & Fair \\
Teamwork & Fair & Medium \\
System thinking & Fair & Fair \\
Broader context & Good & Medium \\
\hline
\end{tabular}




\section{Conclusions}

This research concerned the integration of an open platform in various fields for final year students or pre-engineer learners. It met requirements compelled by Engineering Project in Community Service and demands from industry.

The authors have spent several years joining and teaching in PBL and EPICS classes. We realize that this was a new education approach when combining the EPICS program with practical applications, which involved:

- $\quad$ AGV-based open platform for multidisciplinary majors: The hardware was built up to be similar with an industrial system by manufacturing a tool machine. With an open 3D technical drawing, it was easy to manufacture in workshop anywhere. To simply access the hardware, a free library with numerous API functions was supported to read/write data. Students could develop a user-defined graphical interface in their field. After training sections, students were able to control the whole system.

- Implementation of educational tools: In the market, the existing commercial hardware systems were different and made for specialized industry. Some of them were inappropriate for teaching owing to price, extendibility, and maintenance. By designing additional components, students could extend more in exercises in the proposed platform.

- Collaborative enhancement: One of the primary conditions in this program is an integrated team that involves undergraduate students in mechatronics, computer science, mechanics, and industrial systems. These teams with complementary skills were committed to one shared purpose: to complete goals and try out approaches for which they held themselves mutually accountable. The think-pair-share technique was useful for this kind of team collaboration.

Author Contributions: Conceptualization, H.Q.T.N.; Methodology, M.-H.P. and H.Q.T.N.; Software, H.Q.T.N.; Validation, M.-H.P. and H.Q.T.N.; Formal Analysis, H.Q.T.N.; Investigation, M.-H.P.; Resources, M.-H.P.; Data Curation, M.-H.P.; Writing-Original Draft Preparation, H.Q.T.N.; Writing-Review and Editing, M.-H.P. and H.Q.T.N.; Visualization, H.Q.T.N.; Supervision, M.-H.P.; Project Administration, H.Q.T.N.; Funding Acquisition, M.-H.P.

Funding: This research was partially funded by USAID, BUILD-IT, and Arizona State University through EPICS program in Vietnam.

Acknowledgments: Authors would like to thank USAID, BUILD-IT, and Arizona State University in the EPICS program in Vietnam. Visit our homepage at (https:/ / builditvietnam.org/events/epics2018).

Conflicts of Interest: The authors declare no conflict of interest. 


\section{Appendix A}

Table A1. Evaluations of Design Process.

\begin{tabular}{|c|c|c|c|c|c|}
\hline & Criteria & Four Driving Wheels & Two Driving Wheels, Two Castor Wheels & One Driving Wheels, Two Castor Wheels & $\begin{array}{l}\text { None Driving Wheels, } \\
\text { Four Castor Wheels }\end{array}$ \\
\hline \multirow{3}{*}{$\begin{array}{l}\text { Electrical } \\
\text { subsystem }\end{array}$} & Schematic & Four DC motor drivers & Two DC motor drivers & One DC motor drivers & No DC motor drivers \\
\hline & Safety & All connectors tightly and insulated & Most connectors tightly and insulated & Connectors somewhat tight and insulated & $\begin{array}{l}\text { No connectors were tight } \\
\text { and insulated }\end{array}$ \\
\hline & Fashionable & Absolutely reasonable layout & Mostly reasonable layout & Somewhat reasonable layout & Not a reasonable layout \\
\hline \multirow{4}{*}{$\begin{array}{l}\text { Control } \\
\text { program }\end{array}$} & $\begin{array}{l}\text { Program } \\
\text { requirements }\end{array}$ & $\begin{array}{l}\text { The control program can: } \\
-\quad \text { drive four wheels simultaneously. } \\
-\quad \text { turn left or right based on two } \\
\text { driving wheels at front side } \\
\text { operate 5-6 tasks of all tasks }\end{array}$ & $\begin{array}{l}\text { The control program can: } \\
-\quad \text { drive two wheels simultaneously } \\
\text { - } \quad \text { turn left or right based on two } \\
\text { driving wheels at middle } \\
\text { operate 3-4 tasks of all tasks }\end{array}$ & $\begin{array}{l}\text { The control program can: } \\
-\quad \text { only drive one wheel } \\
\text { - } \quad \text { turn left or right based on one } \\
\text { driving wheel at front side } \\
\text { and middle } \\
\text { - } \quad \text { operate 3-4 tasks of all tasks }\end{array}$ & $\begin{array}{l}\text { The control program cannot } \\
\text { operate any tasks }\end{array}$ \\
\hline & Program structure & $\begin{array}{l}\text { Contains sub-functions that fully describe } \\
\text { four parts in order: definition, } \\
\text { initialization (setup function), main } \\
\text { process (loop function), and sub-functions }\end{array}$ & Contain several sub-functions in order & Contains a few sub-functions in order & Does not contain sub-functions \\
\hline & Readable & $\begin{array}{l}\text { Code must contain: } \\
\text { comments on all initialization, } \\
\text { sub-functions, variables at least } 30 \% \\
\text { of comments on process lines of code } \\
\text { variables and functions name } \\
\text { are meaningful }\end{array}$ & $\begin{array}{l}\text { Code contains both criteria, comments and } \\
\text { variable and function naming but one } \\
\text { criterion be wrong }\end{array}$ & $\begin{array}{l}\text { Code contains one of criterion, } \\
\text { comments and variable and function } \\
\text { naming or code contain both criterion but } \\
\text { they all be wrong }\end{array}$ & $\begin{array}{l}\text { Not comment at all } \\
\text { variables and functions name are } \\
\text { not meaningful }\end{array}$ \\
\hline & Algorithm & $\begin{array}{l}\text { Algorithm must contain: input, output, } \\
\text { definiteness, effectiveness, and termination }\end{array}$ & $\begin{array}{l}\text { Algorithm contains 3-4 criteria } \\
\text { in all criterion }\end{array}$ & $\begin{array}{l}\text { Algorithm contains 1-2 criteria } \\
\text { in all criterion }\end{array}$ & Not any criteria \\
\hline \multirow{4}{*}{$\begin{array}{l}\text { Physical } \\
\text { structure }\end{array}$} & $\begin{array}{l}\text { Full load/distance } \\
\text { requirement }\end{array}$ & Full load and distance & Meet $<80 \%$ of load and distance & Meet $<60 \%$ of load and distance & Meet $<50 \%$ of load and distance \\
\hline & Structure & $\begin{array}{l}\text { - Complicated, it is hard to install, } \\
\text { adjust, and dismantle } \\
\text { - } \quad \text { Using large scale of different } \\
\text { types materials } \\
\text { - } \quad \text { Using large scale of } \\
\text { unpopular materials }\end{array}$ & $\begin{array}{ll}\text { - } & \text { Fairly easy to install and dismantle } \\
\text { - } & \text { Using many types of } \\
\text { different materials } \\
\text { - } & \text { Using many unpopular materials }\end{array}$ & $\begin{array}{ll}\text { - } & \text { Messy structure to install, adjusting } \\
\text { and dismantle } \\
\text { - } \\
\text { Using several types of } \\
\text { different materials } \\
\text { - } \quad \text { Using several unpopular materials }\end{array}$ & 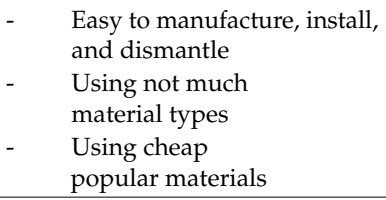 \\
\hline & Designed creation & $\begin{array}{l}\text { Requires self-developed actuators } \\
\text { due to limitation of domestic device } \\
\text { and finance } \\
\text { Having the ability to upgrade }\end{array}$ & $\begin{array}{l}\text { The product is based on an existing } \\
\text { one, but has some different parts }\end{array}$ & $\begin{array}{l}\text { - } \quad \text { It is similar as an existing product } \\
\text { - } \quad \text { It does not upgrade }\end{array}$ & $\begin{array}{l}\text { - The same as } \\
\text { existing product }\end{array}$ \\
\hline & Safety operation & $\begin{array}{ll}\text { - } & \text { Absolute firmness of mechanism } \\
\text { - } & \text { Operates totally without vibration }\end{array}$ & $\begin{array}{ll}\text { - } & \text { Medium firmness of mechanism } \\
\text { - } & \text { Structure has a little bit of vibration }\end{array}$ & $\begin{array}{ll}- & \text { Less firm mechanism } \\
- & \text { Structure has some of vibration }\end{array}$ & $\begin{array}{ll}\text { - } & \text { Unstable structure } \\
\text { - } & \text { Operator requires care } \\
\text { to operate }\end{array}$ \\
\hline
\end{tabular}




\section{Appendix B}

Table A2. Evaluations of Team Presentation

\begin{tabular}{|c|c|c|c|c|}
\hline & 4 & 3 & 2 & 1 \\
\hline \multirow{4}{*}{$\begin{array}{c}\text { Oral } \\
\text { demonstration }\end{array}$} & $\begin{array}{l}\text { Speak loud enough for } \\
\text { everyone to hear }\end{array}$ & $\begin{array}{l}\text { Speak with medium voice and } \\
\text { somebody cannot hear }\end{array}$ & $\begin{array}{l}\text { Speak too soft that many in the } \\
\text { audience cannot to hear }\end{array}$ & Mumble their presentation \\
\hline & Speaking speed reasonable & $\begin{array}{l}\text { Speaking speed sometimes too slow or } \\
\text { too fast }\end{array}$ & Speaking speed too slow or too fast & Speaking with a halt \\
\hline & $\begin{array}{l}\text { Combine well with the operation of } \\
\text { open platform }\end{array}$ & $\begin{array}{l}\text { Combine pretty well with the operation } \\
\text { of open platform }\end{array}$ & $\begin{array}{l}\text { Combine poorly with the operation of } \\
\text { open platform }\end{array}$ & $\begin{array}{l}\text { Presentation not combine with the } \\
\text { operation of open platform }\end{array}$ \\
\hline & Good body language, good eye contact & $\begin{array}{l}\text { Good body language, good eye contact } \\
\text { but sometime look nowhere }\end{array}$ & $\begin{array}{l}\text { Body language is not good, just focus } \\
\text { one side }\end{array}$ & Shows little care for the audience \\
\hline \multirow{3}{*}{$\begin{array}{l}\text { Project } \\
\text { notebook }\end{array}$} & $\begin{array}{l}\text { Enough information about bill of } \\
\text { materials (size, picture, web link, } \\
\text { quantity), easy to identify materials }\end{array}$ & $\begin{array}{l}\text { Enough information but some } \\
\text { materials that are hard to identify }\end{array}$ & $\begin{array}{l}\text { Lack information about bill of materials } \\
\text { and hard to identify materials }\end{array}$ & $\begin{array}{l}\text { Lack information about bill of materials } \\
\text { and cannot identify material }\end{array}$ \\
\hline & Design drawing similar to the model & Design drawing similar to the model & Design drawing different to the model & Design drawing different to the model \\
\hline & Assignment task and schedule clearly & $\begin{array}{l}\text { Assignment task and schedule } \\
\text { is not clearly }\end{array}$ & $\begin{array}{l}\text { Assignment task and schedule is } \\
\text { missing some roles }\end{array}$ & No assignment task and not schedule \\
\hline
\end{tabular}

\section{Appendix C}

Table A3. Evaluations of Team Activities.

\begin{tabular}{|c|c|c|c|c|}
\hline & 4 & 3 & 2 & 1 \\
\hline $\begin{array}{l}\text { Team role/shared } \\
\text { leadership }\end{array}$ & $\begin{array}{l}\text { Each role (note taker or time keeper or } \\
\text { reporter or facilitator or team member) } \\
\text { in team finished their roles excellently } \\
\text { and always met the deadline }\end{array}$ & $\begin{array}{l}\text { Each role (note taker or time keeper or } \\
\text { reporter or facilitator or team member) } \\
\text { in team finished their roles well and } \\
\text { meet the deadline most of the time }\end{array}$ & $\begin{array}{l}\text { Each role (note taker or time keeper or } \\
\text { reporter or facilitator or team member) in } \\
\text { team finished their roles but sometime } \\
\text { did not meet the deadline }\end{array}$ & $\begin{array}{l}\text { Each role (note taker or time keeper } \\
\text { or reporter or facilitator or team } \\
\text { member) in team did not finish } \\
\text { their role by the deadline }\end{array}$ \\
\hline Participation/collaboration & $\begin{array}{l}\text { Member enthusiastically took part and } \\
\text { supported others in the project }\end{array}$ & $\begin{array}{l}\text { Member took part and supported } \\
\text { others most in the project }\end{array}$ & $\begin{array}{l}\text { Member partly took part and supported } \\
\text { others in the project }\end{array}$ & $\begin{array}{l}\text { Member rarely took part and } \\
\text { supported others in the project }\end{array}$ \\
\hline $\begin{array}{l}\text { Work quality/research } \\
\text { and information }\end{array}$ & $\begin{array}{l}\text { Member finished their technical tasks } \\
\text { excellently (mechanical or electrical } \\
\text { or control) }\end{array}$ & $\begin{array}{l}\text { Member finished their technical tasks } \\
\text { well (mechanical or electrical } \\
\text { or control) }\end{array}$ & $\begin{array}{l}\text { Member partly finished their technical } \\
\text { tasks (mechanical or electrical or control) }\end{array}$ & $\begin{array}{l}\text { Member poorly finished their } \\
\text { technical tasks (mechanical or } \\
\text { electrical or control) }\end{array}$ \\
\hline
\end{tabular}




\section{References}

1. Oakes, W.; John, S. EPICS: Engineering Projects in Community Service. In Proceedings of the 34th Annual Frontiers in Education, Savannah, GA, USA, 20-23 October 2004.

2. Coyle, E.J.; Leah, H.J.; William, C.O. EPICS: Engineering projects in community service. Int. J. Eng. Educ. 2005, 21, 139-150.

3. Nasser, H.; Mohammad, R.H. Application of Project-Based Learning (PBL) to the Teaching of Electrical Power Systems Engineering. IEEE Trans. Educ. 2012, 55, 495-501. [CrossRef]

4. Aaron, M.K.; David, C.J.; Matthew, B.B.; Matthew, E.D. Bioinstrumentation: A Project-based Engineering Course. IEEE Trans. Educ. 2016, 59, 52-58. [CrossRef]

5. Ho, M.L.; Rad, A.B.; Chan, P.T. Project-based Learning: Design of a prototype semiautonomous vehicle. IEEE Control Syst. Mag. 2004, 24, 88-91. [CrossRef]

6. Laio, O.S.; Romeu, H.; Eduardo, A.B. Agent-based Simulation of Learning Dissemination in a Project-based Learning Context Considering the Human Aspects. IEEE Trans. Educ. 2018, 61, 101-108. [CrossRef]

7. Ngo, H.Q.T.; Nguyen, T.P.; Huynh, V.N.S.; Le, T.S.; Nguyen, C.T. Experimental Comparison of Complementary Filter and Kalman Filter Design for Low-cost Sensor in Quadcopter. In Proceedings of the IEEE International Conference on System Science and Engineering, Ho Chi Minh City, Vietnam, 21-23 July 2017; pp. 488-493. [CrossRef]

8. $\quad$ Blumenfeld, P.C.; Elliot, S.; Ronald, W.M.; Joseph, S.K.; Mark, G.; Annemarie, P. Motivating project-based learning: Sustaining the doing, supporting the learning. Educ. Psychol. 1991, 26, 369-398. [CrossRef]

9. Barron, B.J.S.; Schwartz, D.L.; Vye, N.J.; Moore, A.; Petrosino, A.; Zech, L.; Bransford, J. Doing with understanding: Lessons from research on problem-and project-based learning. J. Learn. Sci. 1998, 7, 271-311. [CrossRef]

10. Thomas, J.W. A Review of Research on Project-Based Learning. 2000. Available online: https:/ /documents.sd61. bc.ca/ANED/educationalResources/StudentSuccess/A_Review_of_Research_on_Project_Based_Learning.pdf (accessed on 20 December 2018).

11. Stephanie, B. Project-based learning for the 21st century: Skills for the future. Clear. House 2010, 83, 39-43. [CrossRef]

12. Wiek, A.; Xiong, A.; Brundiers, K.; van der Leeuw, S. Integrating problem-and project-based learning into sustainability programs: A case study on the School of Sustainability at Arizona State University. Int. J. Sustain. High. Educ. 2014, 15, 431-449. [CrossRef]

13. Kricsfalusy, V.; Colleen, G.; Maureen, G.R. Integrating problem-and project-based learning opportunities: Assessing outcomes of a field course in environment and sustainability. Environ. Educ. Res. 2018, 24, 593-610. [CrossRef]

14. Wurdinger, S.; Mariam, Q. Enhancing college students' life skills through project-based learning. Innov. High. Educ. 2015, 40, 279-286. [CrossRef]

15. Baş, G.; Ömer, B. Effects of multiple intelligences supported project-based learning on students' achievement levels and attitudes towards English lesson. Int. Electron. J. Elem. Educ. 2017, 2, 365-386.

16. Ai, O. Exploring the Potential of CLIL in English Language Teaching in Japan Universities: An Innovation for the Development of Effective Teaching and Global Awareness. J. Rikkyo Univ. Lang. Center 2014, 32, 39-51.

17. Lastra-Mercado, D. An Introductory Study of Project-Based Learning (PBL) and Content and Language Integrated Learning (CLIL) in TEFL; Universidad de Jaén: Jaén, Spain, 2016.

18. Tawfik, A.A.; Lilly, C. Using a flipped classroom approach to support problem-based learning. Technol. Knowl. Learn. 2015, 20, 299-315. [CrossRef]

19. Rahman, A.A.; Zaid, N.M.; Abdullah, Z.; Mohamed, H.; Aris, B. Emerging Project Based Learning in Flipped Cclassroom: Technology Used to Increase Students' Engagement. In Proceedings of the 3rd International Conference on Information and Communication Technology (ICoICT), Nusa Dua, Indonesia, 27-29 May 2015.

20. Tsai, C.W.; Shen, P.D.; Lu, Y.J. The effects of problem-based learning with flipped classroom on elementary students' computing skills: A case study of the production of ebooks. Int. J. Inf. Commun. Technol. Educ. (IJICTE) 2015, 11, 32-40. [CrossRef]

21. Shih, W.L.; Tsai, C.Y. Students' perception of a flipped classroom approach to facilitating online project-based learning in marketing research courses. Aust. J. Educ. Technol. 2017, 33. [CrossRef] 
22. Cukurbasi, B.; Kiyici, M. High school students' views on the PBL activities supported via flipped classroom and LEGO practices. J. Educ. Technol. Soc. 2018, 21, 46-61.

23. Ngo, H.Q.T.; Nguyen, Q.C.; Nguyen, T.P. Design and Implementation of High Performance Motion Controller for 2-D Delta Robot. In In Proceedings of the Seventh International Conference on Information Science and Technology, Da Nang, Vietnam, 16-19 April 2017; pp. 129-134. [CrossRef]

24. Cheryl, Z.Q.; Carla, Z.; William, O. Collaborating Interaction Design into Engineering Projects in Community Service (EPICS). In Proceedings of the 2012 Frontiers in Education Conference Proceedings, Seattle, WA, USA, 3-6 October 2012; pp. 1-6. [CrossRef]

25. Jonathan, P.S.; Panagiotis, K.L. EPICS: A Service Learning Program at Butler University. In Proceedings of the Frontiers in Education 35th Annual Conference, Indianopolis, IN, USA, 19-22 October 2005; pp. 21-25. [CrossRef]

26. Srijoy, D.; Rohan, M. EPICS High: Digital Literacy Project in India. In Proceedings of the 2014 IEEE Integrated STEM Education Conference, Princeton, NJ, USA, 8 March 2014; pp. 1-6. [CrossRef]

27. Srijoy, D.; Rohan, M. EPICS High: STEM's impact on community service. In Proceedings of the 2013 IEEE Integrated STEM Education Conference (ISEC), Princeton, NJ, USA, 9 March 2013; pp. 1-4. [CrossRef]

28. Carla, B.Z.; William, C.O. Learning by Doing: Reflections of the EPICS Program. Int. J. Serv. Learn. Eng. 2014, 9, 1-32. [CrossRef]

29. Angela, R.B.; Kurtis, G.P.; Christopher, W.S. Measuring the Value Added from Service Learning in Project-based Engineering Education. Int. J. Eng. Educ. 2010, 26, 535-546.

30. Luis, C.; Marta, R.; Lidon, M.; Teresa, G. University Social Responsibility towards Engineering Undergraduates: The Effect of Methodology on a Service-Learning Experience. Sustainability 2018, 10, 1823. [CrossRef]

31. Joachim, W.; Nicola, W.S.; Nadia, N.K. Quality in Interpretive Engineering Education Research: Reflections on an Example Study. J. Eng. Educ. 2013, 102, 626-659. [CrossRef]

32. James, L.H.; Carla, B.Z.; William, C.O. Preparing Engineers for the Workplace through Service Learning: Perceptions of EPICS Alumni. J. Eng. Educ. 2016, 105, 43-69. [CrossRef]

33. Ghiani, G.; Laporte, G.; Musmanno, R. Introducing logistics system. In Introduction to Logistics System Planning and Control; Ross, S., Weber, R., Eds.; John Willey \& Son: Chichester, UK, 2004; pp. 1-22, ISBN 0-470-84916-9.

34. Whelan, P.L. Material Handling System and Method for Manufacturing Line. U.S. Patent 4,293,249, 6 October 1981.

35. Kadaba, N. Special Handling Processing in a Package Transportation System. U.S. Patent 6,539,360, 25 March 2003.

36. Thatcher, J.L.; Easterling, A. Automated Order Filling Method and System. U.S. Patent 6,505,093, 7 January 2003.

37. Mountz, M.C. Material Handling System Using Autonomous Mobile Drive Units and Movable Inventory Trays. U.S. Patent 6,895,301, 17 May 2005.

38. Mountz, MC. Material Handling System and Method Using Mobile Autonomous Inventory Trays and Peer-to-Peer Communications. U.S. Patent 6,950,722, 27 September 2005.

39. Ito, T.; Mousavi Jahan Abadi, S.M. Agent-based material handling and inventory planning in warehouse. J. Intell. Manuf. 2002, 13, 201-210. [CrossRef]

40. Babiceanu, R.F.; Chen, F.F.; Sturges, R.H. Framework for the control of automated material-handling systems using the holonic manufacturing approach. Int. J. Prod. Res. 2004, 42, 3551-3564. [CrossRef]

41. Chow, H.K.; Choy, K.L.; Lee, W.B.; Lau, K.C. Design of a RFID case-based resource management system for warehouse operations. Expert Syst. Appl. 2006, 30, 561-576. [CrossRef]

42. Ting, L.; Peijiang, Y.; Tianmiao, W.; Chengkun, W.; Dongdong, C.; Yong, L. An AGV-based Teaching Approach on Experiments of Mechatronics Course. In Proceedings of the 2014 IEEE International Conference on Robotics and Biomimetics (ROBIO 2014), Bali, Indonesia, 5-10 December 2014; pp. 2104-2109. [CrossRef]

43. Hector, P.; Eugenio, V.; Fernando, H. Using JIGSAW-type Collaborative Learning for Integrating Foreign Students in Embedded System Engineering. In Proceedings of the Design of Circuits and Integrated Systems, Madrid, Spain, 26-28 November 2014; pp. 1-6. [CrossRef]

44. Paulik, M.J.; Krishnan, M. An autonomous ground vehicle competition-driven capstone design course. In Proceedings of the 29th ASEE/IEEE Frontiers in Education Conference, San Juan, PR, USA, 10-13 November 1999; Volume 2, pp. 7-12. [CrossRef]

45. Julio, V.; Jose, M.C. PiBot: An Open Low-Cost Robotic Platform with Camera for STEM Education. Electronics 2018, 7, 430. [CrossRef] 
46. Timothy, D.; Nicole, H.; Gautam, B. Design and Development of a Low-Cost Open-Source Robotics Education Platform. In Proceedings of the 50th International Symposium on Robotics, Munich, Germany, 20-21 June 2018; pp. 1-4.

47. Paulo, A.F.R.; Hector, A.; Luiz, C. HeRo: An open platform for robotics research and education. In Proceedings of the Latin American Robotics Symposium and Brazilian Symposium on Robotics, Curitiba, Brazil, 8-11 November 2017; pp. 1-6. [CrossRef]

48. Marsette, V.; Shekar, N.H. Teaching Robotics Software with the Open Hardware Mobile Manipulator. IEEE Trans. Educ. 2013, 56, 42-47. [CrossRef]

49. Pedro, J.N.; Carlos, F.; Pedro, S. Industrial-Like Vehicle Platforms for Postgraduate Laboratory Courses on Robotics. IEEE Trans. Educ. 2013, 56, 34-41. [CrossRef]

50. Lorenz, M.; Dominik, H.; Marc, P. PX4: A node-based multithreaded open source robotics framework for deeply embedded platforms. In Proceedings of the 2015 IEEE International Conference on Robotics and Automation (ICRA), Seattle, WA, USA, 26-30 May 2015; pp. 6235-6240. [CrossRef]

51. Marta, M.; Juan, C.G.; Lukasz, K.; Pedro, D.M.; David, P.; Javier, L. Open platform and open software for an intelligent wheelchair with autonomous navigation using sensor fusion. In Proceedings of the 42nd Annual Conference of the IEEE Industrial Electronics Society, Florence, Italy, 23-26 October 2016; pp. 5929-5934. [CrossRef]

52. USAID/Vietnam Director Talks with VTC10 Channel about the Engineering Projects in Community Service Program 2018 in Vietnam. Available online: https:/ /goo.gl/oczFa7 (accessed on 10 July 2018).

(C) 2019 by the authors. Licensee MDPI, Basel, Switzerland. This article is an open access article distributed under the terms and conditions of the Creative Commons Attribution (CC BY) license (http:/ / creativecommons.org/licenses/by/4.0/). 